Review

\title{
The RTS,S malaria vaccine
}

\author{
Sofia Casares ${ }^{\mathrm{a}, \mathrm{b}, *}$, Teodor-Doru Brumeanu ${ }^{\mathrm{b}}$, Thomas L. Richie ${ }^{\mathrm{a}}$ \\ a US Military Malaria Vaccine Program, Naval Medical Research Center/Walter Reed Army Institute of Research, Silver Spring, MD, USA \\ ${ }^{\mathrm{b}}$ Department of Medicine, Uniformed Services University of Health Sciences, Bethesda, MD, USA
}

\section{A R T I C L E I N F O}

\section{Article history:}

Received 29 March 2010

Received in revised form 29 April 2010

Accepted 12 May 2010

Available online 27 May 2010

\section{Keywords:}

RTS,S

Malaria vaccine development

Immunology

\begin{abstract}
A B S T R A C T
RTS,S is the most advanced candidate vaccine against human malaria. During its remarkable journey from conception and design in the early 1980s to the multicenter Phase 3 trial currently underway across sub-Saharan Africa, RTS,S has overcome tremendous challenges and disproved established vaccine paradigms. In the last several years, Phase 2 studies conducted in infants and children in endemic areas have established the efficacy of RTS,S for reducing morbidity due to clinical malaria. If the results are realized in the Phase 3 trial, the chances for licensure in the near future appear high. Such progress is all the more remarkable given our lack of clear understanding regarding how the vaccine activates the human immune system, the immune correlates of protection or the mechanism whereby a vaccine targeting sporozoites and liver stage parasites can reduce the clinical disease associated with parasitemia. These unanswered questions pose important challenges to be addressed in the quest to understand the protection afforded by RTS,S and to build a more efficacious second generation vaccine against malaria. This review will focus on current knowledge about the protective efficacy of RTS,S and what we have learned regarding its impact on the human immune system.
\end{abstract}

Published by Elsevier Ltd.

\section{Contents}

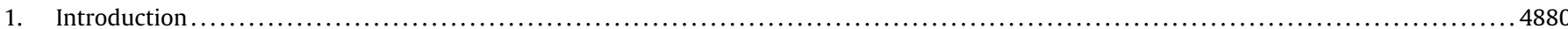

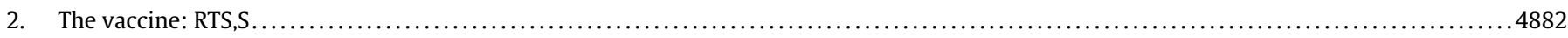

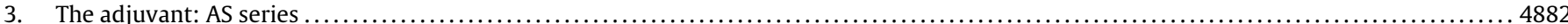

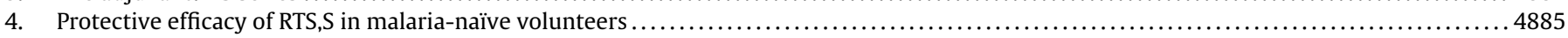

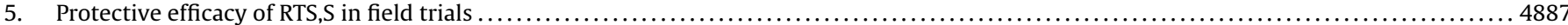

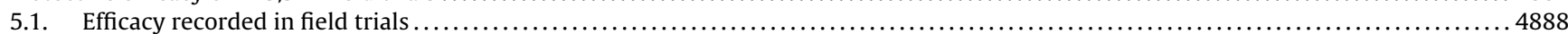

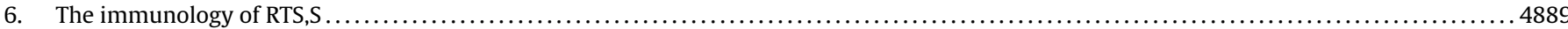

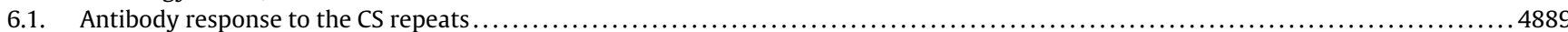

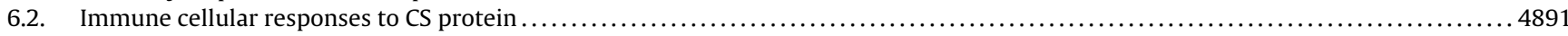

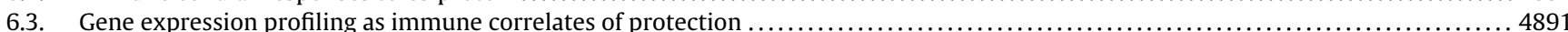

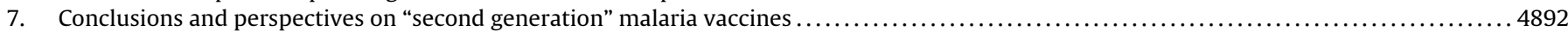

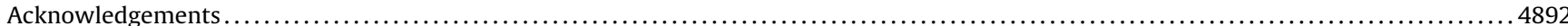

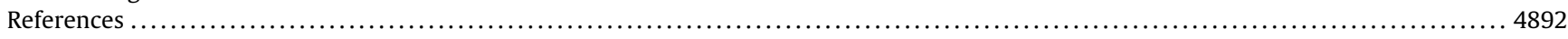

\section{Introduction}

Malaria ("mal aria", the Italian words for "bad air") is an Anopheles mosquito-borne infectious disease caused in humans by five different members of the protozoan genus Plasmodium, occurring commonly in tropical and sub-tropical areas of Africa, Asia, and the Americas, although in the past its range extended far into the

* Corresponding author at: 503 Robert Grant Avenue, Silver Spring, MD 20910 USA. Tel.: +1 301319 7575; fax: +1 3013197545.

E-mail address: sofia.casares@med.navy.mil (S. Casares). temperate regions. There are approximately 250 million cases of clinical malaria resulting in approximately 1 million deaths every year, mainly affecting children under the age of 5 years living in sub-Saharan Africa, but also affecting other risk groups including pregnant women and non-immune adults such as tourists or military personnel traveling to or deployed to endemic areas. Though malaria had once affected much of Europe and the US, it was eliminated by the 1950s, 1960s and early 1970s in most temperate regions by anti-malarial chemotherapy campaigns and vector control programs [1]. The success of these initiatives proved that malaria could be eliminated without the assistance of a vaccine. However, control and elimination have been much more difficult 
in tropical areas for a variety of reasons. The most fundamental is likely the fact that excellent vectors, uninterrupted transmission and other factors have led to rates of transmission in tropical areas far exceeding the minimum rate required to maintain the parasite in the human reservoir. This necessitates a more effective and drastic reduction in transmission to eliminate the parasite compared with what was required for temperate regions. This barrier has been compounded by the poor health care delivery, weak environmental controls and inadequate economic resourcing characterizing many of the countries where malaria in entrenched. Unfortunately, due to these and other factors, the international malaria eradication program was abandoned in the 1970s, such that malaria remains among the most, if not the most important infectious disease for people living in economically disadvantaged countries in tropical and some sub-tropical regions, where poverty, struggling health systems, and political instability prevail.

The emergence of drug-resistant strains of Plasmodium falciparum and $P$. vivax and insecticide-resistant mosquitoes poses a growing threat for malaria-endemic countries, even as recent evidence points to success in malaria control in many areas. Moreover, the disease presents an ongoing threat for travelers to and within malaria-endemic countries, compromising economic development in addition to its direct effects on the health of endemic populations. The effort to generate a malaria vaccine thus remains prioritized, an urgent need not only for health reasons but to foster political stability and economic growth. Non-government organizations, exemplified by the Bill and Melinda Gates Foundation, are supplementing traditional sources of funding for vaccine development with new avenues for support and new calls for elimination and eradication.

The life cycle of malaria parasites in the human host is complex and entails an asymptomatic liver stage (pre-erythrocytic) infection followed by a symptomatic blood stage (erythrocytic) infection (Fig. 1). The parasite's life cycle within the liver is very short: 2 days for rodent malaria parasites and 5-6 days for $P$. falciparum. It was thus doubted that immune responses induced by vaccination against liver stage parasites could act quickly enough to destroy the infected hepatocytes and to prevent the release of liver-stage merozoites into the blood. In the early 1960s, Nussenzweig et al. at New York University demonstrated that immunization of animals with the bites of irradiated-attenuated infected mosquitoes could protect against challenge with infectious sporozoites [2] and this finding was soon extended to human volunteers. The observation of high grade protection in humans overcame any doubts regarding the feasibility of a pre-erythrocytic stage vaccine, and set a benchmark in the field of high-level $(>90 \%)$ sterile protection. The attenuated sporozoite approach was however considered impractical for human vaccination purposes due to the inability to generate sporozoites other than within the mosquito, and the difficulties associated with immunization via mosquito bite. This new paradigm has recently been challenged by Hoffman and co-workers, who are attempting to develop a vaccine based on irradiation-attenuated sporozoites.

The Nussenzweig's discovery led to the identification of the circumsporozoite (CS) protein expressed on sporozoites and liver stage schizonts $[3,4]$. The CS protein has a molecular size of $58 \mathrm{kD}$ and contains a central repeat region flanked on each site by a non-repetitive region (Fig. 2). The central region contains approximately 41 repeats (range 37-49) of NANP (N, asparagine; A, alanine; $P$, proline) amino acid sequences and a smaller number of NVDP (V, valine; $\mathrm{D}$, aspartic acid) sequences. The function of the central repeat region is still unknown but most likely offers a significant adaptive advantage to the parasite, since it is highly conserved among different strains of $P$. falciparum. Most of the mutations identified in the central repeat region have led to expansions or contractions in the number of repeats and to a conversion of NANP

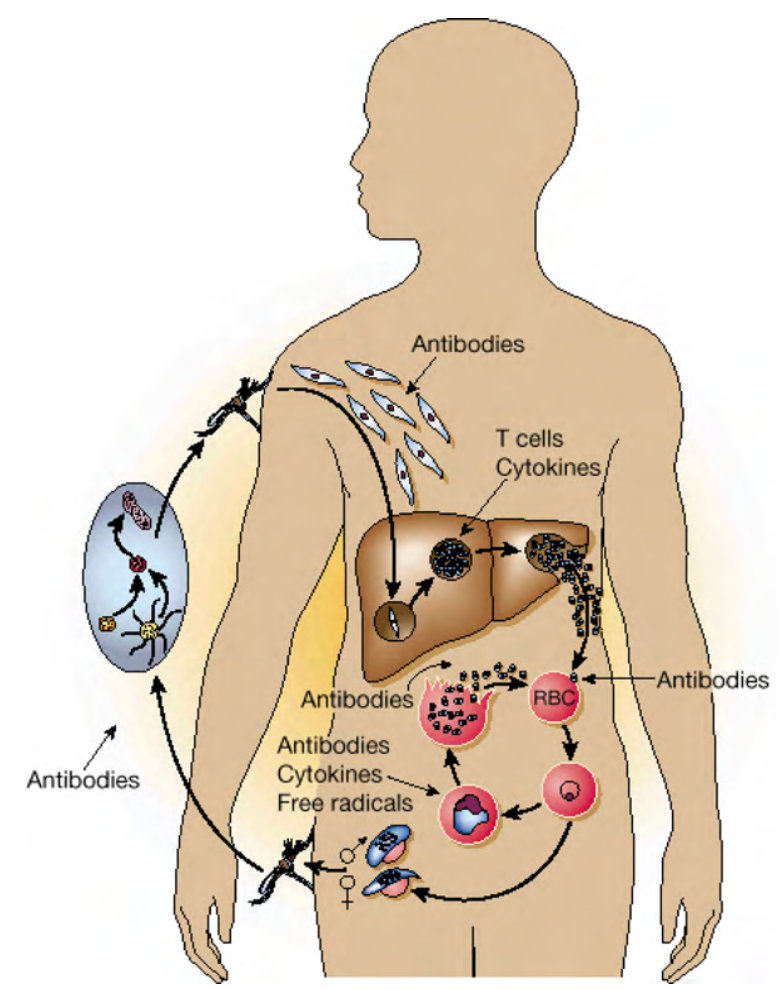

Fig. 1. The life cycle of Plasmodium falciparum. P. falciparum has a complex life cycle that involves an arthropod and a human host. In the human host, the cycle begins with the bite of an infected Anopheles female mosquito that delivers sporozoites into the skin. The sporozoites enter the blood circulation and migrate to the liver where they infect hepatocytes and develop into liver stage merozoites. The merozoites are released from the infected hepatocytes and invade red blood cells (RBC) where they develop into blood stage merozoites. The disease is then perpetuated by continuous cycles of RBC infection and merozoite release, the latter associated with the paroxysms (chills and fever) characteristic of malaria. During the course of blood infection, some merozoites differentiate into female or male gametocytes that are taken by the mosquito. In the mosquito gut gametocytes undergo sexual reproduction and meiosis and further clonal expansion to generate sporozoites that migrate to the salivary glands. The types of immune responses known to protect against the different parasite forms are indicated by arrows. Protective humoral responses have been shown to be T cell dependent which indicates that CD4 T helper (Th) cells play a critical role in immunity against malaria.

sequences into NVDP sequences, or vice versa [5]. The N-terminus region of CS protein is conserved among strains of $P$. falciparum and contains a motif of 5 amino acids $\left({ }^{93} \mathrm{KLKQP}^{97}\right)$, which is also shared by all mammalian sporozoites [6]), and known to be involved in sporozoite invasion of mosquito salivary glands as well as in binding to hepatocytes prior to invasion $[7,8]$. The C-terminus region is involved in the invasion of mosquito salivary glands, sporozoite mobility, and invasion of hepatocytes [9] but unlike the N-terminus, it is highly polymorphic. As recognized by the human immune system, the central repeat region contains immunodominant $\mathrm{B}$ cell epitopes and the flanking C-terminal region contains both $\mathrm{B}$ and $\mathrm{T}$ cell epitopes (termed Th2R and Th3R) which demonstrate a high

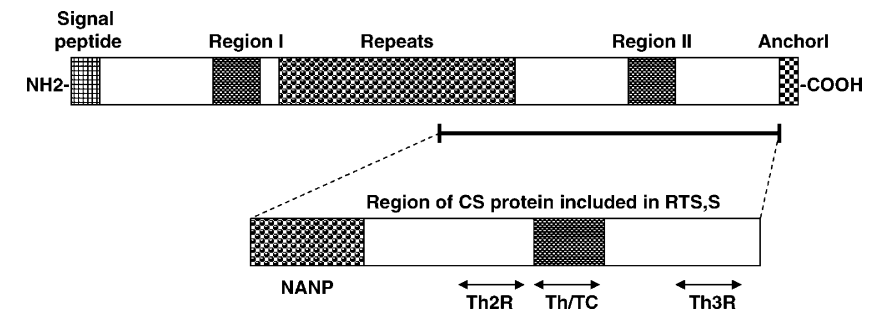

Fig. 2. Schematic representation of CS protein. 
level of polymorphism [10]. A universal T cell epitope recognized by $\mathrm{T}$ cells in the context of multiple HLA-DR molecules was also identified as residues $326-345$.

Since the irradiated-sporozoite approach was considered impractical as a vaccine, investigators attempted to create sub-unit vaccines based on CS protein. Clinical trials were then initiated to test the immunogenicity and protective efficacy of $P$. falciparum CS protein (PfCSP) in the form of recombinant DNA [11], full-length recombinant PfCSP [12], recombinant PfCSP lacking the central repeats [13], and PfCSP repeat peptides coupled to highly immunogenic carriers (i.e, Pseudomonas. aeruginosa toxin A or tetanus toxid) $[14,15]$. Though the vaccines showed some degree of immunogenicity as they elicited humoral and/or cellular responses to the CS protein, there was little or no protection against sporozoite challenge. Thus it became clear that soluble, recombinant PfCSP is a poor immunogen for humans, and that a better vaccine platform including potent adjuvants was required to achieve protection. The poor immunogenicity of PfCSP was also supported by data indicating that humans living in malaria-endemic areas develop weak humoral and cellular responses to CS protein, despite frequent (often daily) exposure to the sporozoites of $P$. falciparum in regions with high entomologic inoculation rates [16].

\section{The vaccine: RTS,S}

Previous research on hepatitis B virus demonstrated that the primary viral surface proteins (HBsAg, also known as $\mathrm{S}$ antigen) if present at sufficient concentration could assemble spontaneously into viral particles devoid of DNA [17]. The construct was licensed in the 1980s and used as an effective vaccine against hepatitis B able to elicit neutralizing antibodies and to prevent infection. Rutgers et al. [18] at Glaxo-Smith-Kline (GSK) in collaboration with Walter Reed Army Institute of Research (WRAIR) then tested the hypothesis that using HBsAg as a matrix carrier for $P$. falciparum CS protein would increase its immunogenicity and achieve high-level protection against malaria. The first construct developed at GSK/WRAIR was made of PfCSP NANP repeat region fused at the N-terminus of HbsAg and produced in yeast cells (Saccharomyces cerevisiae). The fusion protein (named R16HBsAg) was able to assemble into viral particles that induced CS antibodies in mice [18]. There was however the concern that the construct lacked the T cell epitopes at the C-terminal flanking region of CS protein, which would be required for induction of specific T cell responses. This led to the generation of a second CS protein construct expressing 19 NANP repeats of the central region and the entire C-terminal flanking region (amino acids 207-395) from P. falciparum strain NF54, clone 3D7 (Fig. 2). To stabilize the recombinant viral particles, the fusion protein was co-expressed in yeast cells with wild-type HBsAg (S) antigen. The result was the RTS,S product that is comprised of $25 \%$ fusion protein RTS (B cell Repeats + T cell epitopes + HBsAg (S) antigen) and 75\% wild-type HBsAg (S) antigen [19].

RTS,S was designed as a human vaccine, and no ortholog vaccine constructs for rodent or monkey models of malaria have been published in the literature. Thus, the RTS,S pre-clinical studies have been based on safety and immunogenicity only. Unlike the hepatitis $B$ vaccine which is highly immunogenic with conventional alum-based adjuvants, RTS,S was not as immunogenic unless it was formulated in novel adjuvants [18].

\section{The adjuvant: AS series}

In order to prevent allergic reactions and autoimmunity, the immune system is generally tolerant to antigens, unless antigens trigger "danger signals" that mobilize the immune system to react aggressively. Adjuvants have been long known for their ability to trigger danger signals and have been widely used for immunization purposes though the specific mechanisms by which the adjuvants work still are not well understood [20]. Common adjuvants are made of aluminium salts, or emulsions such as oil-in-water $(0 / w)$, water-in-oil $(\mathrm{w} / \mathrm{o})$ or water-in-oil-in-water $(\mathrm{w} / \mathrm{o} / \mathrm{w})$ whose function is thought to stabilize antigen and to slow its release to the immune system. The carrier/depot effect of adjuvants seems critical to increase the immunogenicity of antigens because soluble antigens are usually poorly immunogenic. The rate of antigen release however does not necessarily correlate with immunogenicity, as it has been reported [21,22]. To increase the immunogenicity of antigens, adjuvants may additionally contain stimulants such as toll-like-receptors (TLRs) ligands, cytokines, bacterial toxins, or saponins [20].

The adjuvant systems (AS) that have been used with RTS,S were developed by GSK and they are proprietary. Approximate 11 different AS formulations were tested with RTS,S in animals for immunogenicity. Among those that were promising, AS04 (SBAS4), AS03 (SBAS3), AS02 (SBAS2), AS02A and AS01B have been further tested in humans and shown to increase the protection afforded by RTS,S (Table 1). The AS04 adjuvant includes alum and MPL (monophosphoril lipid A), and the AS03 adjuvant is an oil (squalene)-in-water emulsion. MPL is a derivative of lipopolysaccharide (LPS), an endotoxin expressed in the outer membrane of Gram negative bacteria that can lead to septic shock if the bacteria are lysed. LPS triggers danger signals in macrophages and dendritic cells (DCs) and promotes secretion of pro-inflammatory cytokines (i.e., IL-1, IL-12, IL-23) by binding to the lipid binding protein (LBP) in serum and thereafter to CD14 and toll-like-receptor-4 (TLR4) [23]. Antigen presentation to $\mathrm{T}$ cells by these activated macrophages and DCs promotes inflammatory (Th1) responses, characterized by the activation of CD4 T cells that provide help to $\mathrm{B}$ cells to produce cytotoxic antibodies (meaning those isotypes able to activate the complement cascade), and facilitates the recruitment and activation of cytotoxic CD8 T cells (CTLs). AS04 containing MPL is currently licensed for use as an adjuvant for a human papilomavirus/cervical cancer vaccine (www. gsk.com).

AS02 is a squalene-in-water emulsion containing MPL, and QS21. QS21 is a saponin (triterpene glycoside) derived from the bark of the plant Quillaja saponaria that it is thought to function to trap components of the vaccine formulation through hydrophobic interactions and thereby slows their release to the immune system [20]. As RTS,S formulated in ASO2 is locally administered (intramuscularly), the continuous and slow release of antigen and LPS might account for its enhanced immunogenicity and low systemic toxicity, albeit a degree of local reactogenicity has been widely reported in vaccinees. However, whether this is the mechanism of action for AS02 stills need to be addressed [24].

The original ASO2 also contained thimerosal, a mercury-based reagent used as a preservative. Though thimerosal has been long used in many vaccine formulations and there is no proven increase toxicity, concerns over potential neurotoxicity led to its removal from the ASO2 adjuvant by GSK. The new adjuvant contains lactose as a cryopreservant, and it was re-named as AS02A.

RTS,S formulated with AS02 or AS02A confers protection to a significant number of malaria-naïve volunteers as well as in malaria-experienced adults and children in Africa (Tables 1 and 2). In an attempt to increase the immunogenicity of RTS,S, GKS investigators developed a new adjuvant known as AS01B, in which the oil-in-water emulsion of AS02A was replaced by liposomes. The development of the AS01B adjuvant was in part related to previous work by Richards et al. [25] demonstrating that RTS,S encapsulated in liposomes containing MPL, but not in squalene-in-oil emulsion, is delivered to the trans-Golgi in antigen-presenting cells (APCs), where the RTS,S is efficiently processed and enhances MHC class $\mathrm{I}$ and class II antigen presentation to $\mathrm{T}$ cells. Immunization of 
Table 1

Protective efficacy of RTS,S in malaria-naïve volunteers.

\begin{tabular}{|c|c|c|c|c|c|c|c|c|c|}
\hline \multirow[t]{2}{*}{ Center, period } & \multirow{2}{*}{$\begin{array}{l}\text { Age of subjects } \\
\text { in years }\end{array}$} & \multirow[t]{2}{*}{$\mathrm{RTS}, \mathrm{S}$ in adjuvant } & \multirow{2}{*}{$\begin{array}{l}\text { Dose of RTS,S in } \\
\text { volume of adjuvant }\end{array}$} & \multirow{2}{*}{$\begin{array}{l}\text { Time of immuniza- } \\
\text { tion/challenge }\end{array}$} & \multicolumn{2}{|c|}{ Challenge by mosquito bite } & \multicolumn{2}{|c|}{ Re-challenge by mosquito bite } & \multirow[t]{2}{*}{ Ref. } \\
\hline & & & & & $\begin{array}{l}\text { Protection \% } \\
\text { (protected/total } \\
\text { subjects) }\end{array}$ & $\begin{array}{l}\text { Pre-patent period for } \\
\text { unprotected vaccinated } \\
\text { vs. unvaccinated (days) }\end{array}$ & $\begin{array}{l}\text { Protection \% } \\
\text { (protected/total } \\
\text { subjects) }\end{array}$ & $\begin{array}{l}\text { Pre-patent period for } \\
\text { unprotected vaccinated } \\
\text { vs. unvaccinated (days) }\end{array}$ & \\
\hline 1.WRAIR (NR) & $19-28$ & $\begin{array}{l}\mathrm{AS} 04 \\
\mathrm{AS} 03\end{array}$ & $50 \mu \mathrm{g}^{*}$ in $1 \mathrm{ml}$ & $0,2,6 / 6.5$ months & $\begin{array}{l}0(0 / 6) \\
25 \%(2 / 8)\end{array}$ & $\begin{array}{l}11.2 \text { vs. } 10.5(\mathrm{NS}) \\
11 \text { vs. } 11.5(\mathrm{NS})\end{array}$ & ND & & [19] \\
\hline 2.WRAIR (NR) & $18-45$ & $\begin{array}{l}\text { ASO4 } \\
\text { AS03 }\end{array}$ & $\begin{array}{l}50 \mu \mathrm{g}^{*} \text { in } 1 \mathrm{ml} \\
1 \mathrm{st} 50 \mu \mathrm{g}^{*} \text { in } 0.5 \mathrm{ml} \\
\text { 2nd } 50 \mu \mathrm{g}^{*} \text { in } 0.5 \mathrm{ml} \\
\text { 3rd } 10 \mu \mathrm{g}^{*} \text { in } 0.1 \mathrm{ml}\end{array}$ & $0,1,7 / 1$ months & $\begin{array}{l}12.5 \%(1 / 8) \\
28.5 \%(2 / 7)\end{array}$ & $\begin{array}{l}12.6 \text { vs. } 12(\mathrm{NS}) \\
15.2 \text { vs. } 12(p<0.01)\end{array}$ & $\begin{array}{l}100 \%(1 / 1) \\
0 \%(0 / 1)\end{array}$ & 13.2 vs. $10.8(p<0.01)$ & {$[29,34]$} \\
\hline & & AS02 & $\begin{array}{l}\text { 1st } 50 \mu \mathrm{g}^{*} \text { in } 0.5 \mathrm{ml} \\
\text { 2nd } 50 \mu \mathrm{g}^{*} \text { in } 0.5 \mathrm{ml} \\
\text { 3rd } 10 \mu \mathrm{g}^{*} \text { in } 0.1 \mathrm{ml}\end{array}$ & & $85.7 \%(6 / 7)$ & NS & $20 \%(1 / 5)$ & & \\
\hline 3.WRAIR (NR) & $18-45$ & AS02 & $\begin{array}{l}50 \mu \mathrm{g}^{*} \text { in } 0.5 \mathrm{ml} \\
50 \mu \mathrm{g}^{*} \text { in } 0.5 \mathrm{ml} \\
50 \mu \mathrm{g}^{*} \text { in } 0.5 \mathrm{ml} \\
25 \mu \mathrm{g}^{*} \text { in } 0.25 \mathrm{ml} \\
10 \mu \mathrm{g}^{*} \text { in } 0.1 \mathrm{ml}\end{array}$ & $\begin{array}{l}\text { 0/1 month } \\
0,1 / 2 \text { months } \\
0,1,9 / 10 \text { months } \\
0,1,9 / 10 \text { months } \\
0,1,9 / 10 \text { months }\end{array}$ & $\begin{array}{l}30 \%(3 / 10) \\
50 \%(7 / 14) \\
50 \%(3 / 6) \\
57.1 \%(4 / 7) \\
25 \%(1 / 4)\end{array}$ & 14 vs. $12(p<0.005)$ & ND & & [30] \\
\hline 4. WRAIR 2000-2001 & $18-45$ & AS02 & $50 \mu \mathrm{g}$ in $0.5 \mathrm{ml}$ & $\begin{array}{l}0,1,3 / 3.75 \text { months } \\
0,7,28 \text { days/7 weeks }\end{array}$ & $\begin{array}{l}45 \%(9 / 20) \\
39 \%(7 / 18)\end{array}$ & $\begin{array}{l}14 \text { vs. } 11(p<0.001) \\
13 \text { vs. } 11(p<0.001)\end{array}$ & ND & & [32] \\
\hline 5. WRAIR 1995-1998 & $18-45$ & AS02A & $50 \mu \mathrm{g}$ in $0.5 \mathrm{ml}$ & $0,1 / 1.5$ months & $42 \%(8 / 19)$ & 14.5 vs. $12.3(p<0.001)$ & ND & & [31] \\
\hline 6. Oxford 2002-2003 & $21-42$ & $\begin{array}{l}\text { 1st RTS,S/AS02A } \\
\text { 2nd RTS,S/ASO2A } \\
\text { 3rd MVA-CS } \\
\text { 1st MVA-CS } \\
\text { 2nd RTS,S/AS02A } \\
\text { 3rd RTS,S/AS02A }\end{array}$ & $\begin{array}{l}50 \mu \mathrm{g} \text { in } 0.5 \mathrm{ml} \\
50 \mu \mathrm{g} \text { in } 0.5 \mathrm{ml} \\
1 \times 10^{8} \mathrm{pfu} \\
1 \times 10^{8} \mathrm{pfu} \\
50 \mu \mathrm{g} \text { in } 0.5 \mathrm{ml} \\
50 \mu \mathrm{g} \text { in } 0.5 \mathrm{ml}\end{array}$ & $0,1,2 / 3$ months & $33.3 \%(2 / 6)$ & 13.2 vs. $11(p=0.13)$ & $50 \%(1 / 2)$ & NR & [39] \\
\hline 7. WRAIR 2003-2006 & $18-45$ & $\begin{array}{l}\text { AS02A } \\
\text { AS01B }\end{array}$ & $\begin{array}{l}50 \mu \mathrm{g} \text { in } 0.5 \mathrm{ml} \\
50 \mu \mathrm{g} \text { in } 0.5 \mathrm{ml}\end{array}$ & $\begin{array}{l}0,1,2 / 2.5 \text { months } \\
0,1,2 / 2.5 \text { months }\end{array}$ & $\begin{array}{l}32 \%(14 / 44) \\
50 \%(18 / 36)\end{array}$ & $\begin{array}{l}13.6 \text { vs. } 10.8(p<0.001) \\
14.4 \text { vs. } 10.8(p<0.001)\end{array}$ & $\begin{array}{l}44.4 \%(4 / 9) \\
44.4 \%(4 / 9)\end{array}$ & $\begin{array}{l}13.6 \text { vs. } 11.8 \\
14 \text { vs. } 11.8\end{array}$ & [33] \\
\hline
\end{tabular}

NS: not significant; ND: not done; NR, not reported. $\left({ }^{*}\right)$ RTS,S in liquid formulation. 
Table 2

Results of RTS,S vaccine efficacy in field trials.

\begin{tabular}{|c|c|c|c|c|c|c|c|c|c|}
\hline \multirow[t]{2}{*}{ Center period } & \multirow[t]{2}{*}{ Age } & \multirow[t]{2}{*}{$\begin{array}{l}\text { RTS,S in } \\
\text { adjuvant }\end{array}$} & \multirow{2}{*}{$\begin{array}{l}\text { Immunization } \\
\text { time (dose of } \\
\text { RTS,S/volume of } \\
\text { adjuvant) }\end{array}$} & \multirow{2}{*}{$\begin{array}{l}\text { Surveillance } \\
\text { period post- } \\
\text { immunization }\end{array}$} & \multicolumn{4}{|c|}{$\begin{array}{l}\text { Adjusted vaccine efficacy (\%) according-to-protocol analysis (white boxes) or unadjusted } \\
\text { vaccine efficacy (\%) in intention-to-treat analysis (yellow boxes) vaccinated vs. non-vaccinated }\end{array}$} & \multirow[t]{2}{*}{ Ref. } \\
\hline & & & & & $\begin{array}{l}\text { Infection } \\
\text { (subjects/total } \\
\text { subjects) }\end{array}$ & $\begin{array}{l}\text { First or only } \\
\text { clinical episode } \\
\text { (subjects/total } \\
\text { subjects) }\end{array}$ & $\begin{array}{l}\text { All clinical } \\
\text { episodes } \\
\text { (episodes/total } \\
\text { subjects) }\end{array}$ & $\begin{array}{l}\text { Severe malaria } \\
\text { (subjects/total } \\
\text { subjects) }\end{array}$ & \\
\hline \multirow[t]{3}{*}{$\begin{array}{l}\text { Gambia (anti- } \\
\text { malarial) }\end{array}$} & $18-45$ years & AS02 & $\begin{array}{l}0 / 1 / 5 \text { months } \\
(50 \mu \mathrm{g} / 0.5 \mathrm{ml})\end{array}$ & $0-15$ weeks & $34 \%(81 / 131$ vs. $80 / 119)$ & NR & $31 \%(44 / 131$ vs. $50 / 119)$ & NR & [45] \\
\hline & & & & $\begin{array}{l}0-9 \text { weeks/ } \\
9-15 \text { weeks }\end{array}$ & $71 \% / 0 \%$ & & NR & & \\
\hline & & & $\begin{array}{l}\text { Booster dose at } 19 \\
\text { months }\end{array}$ & $0-9$ weeks & $47 \%(19 / 73$ vs. $29 / 86)$ & & $59 \%$ ( $7 / 73$ vs. $22 / 86$ ) & & \\
\hline \multirow[t]{2}{*}{ Kenya } & $18-35$ years & ASO2A & $\begin{array}{l}0 / 1 / 2 \text { months } \\
(50 \mu \mathrm{g} / 0.5 \mathrm{ml})\end{array}$ & $0-14$ weeks & $35 \%$ (28/79 vs. $37 / 75)$ & NR & NR & NR & [46] \\
\hline & & AS01B & & $0-14$ weeks & $11 \%$ (28/74 vs. $37 / 75)$ & & & & \\
\hline \multirow{6}{*}{$\begin{array}{c}\text { Mozambique } \\
\text { (Manhica) } \\
\text { Cohort } 1\end{array}$} & $1-4$ years & $\mathrm{ASO} 2 \mathrm{~A}$ & $\begin{array}{l}0 / 1 / 2 \text { months } \\
(25 \mu \mathrm{g} / 0.25 \mathrm{ml})\end{array}$ & $0-6$ months & $\begin{array}{l}\text { NR Prevalence parasitemia: } \\
11.9 \% \text { vs. } 18.9 \%\end{array}$ & $\begin{array}{l}29.9 \%(123 / 745 \text { vs. } \\
159 / 745)\end{array}$ & $27.4 \%(153 / 745$ vs. $190 / 745)$ & $\begin{array}{l}57.7 \%(11 / 745 \\
\text { vs. } 26 / 745)\end{array}$ & [47] \\
\hline & & & & & & & $30.2 \%$ & & \\
\hline & & & & $6-18.5$ months & NR & $\begin{array}{l}28.9 \%(110 / 723 \text { vs. } \\
140 / 719)\end{array}$ & $28.8 \%$ (157/723 vs. $193 / 719)$ & $\begin{array}{l}38.8 \%(8 / 723 \\
\text { vs. } 13 / 719)\end{array}$ & [48] \\
\hline & & & & $0-18.5$ months & NR (77/666 vs. $106 / 653$ ) & $\begin{array}{l}35.3 \%(186 / 745 \text { vs. } \\
251 / 745)\end{array}$ & $29.8 \%(310 / 745$ vs. $384 / 745)$ & $\begin{array}{l}48.6 \%(19 / 745 \\
\text { vs. } 37 / 745)\end{array}$ & \\
\hline & & & & $0-21$ months & NR & $\begin{array}{l}32.8 \%(224 / 803 \text { vs. } \\
308 / 802)\end{array}$ & $32.4 \%(391 / 803$ vs. $527 / 802)$ & $\begin{array}{l}44.3 \%(24 / 803 \\
\text { vs. } 43 / 802)\end{array}$ & \\
\hline & & & & $0-43$ months & NR (66/541 vs.101/547) & $\begin{array}{l}30.5 \% \text { ( } 307 / 745 \text { vs. } \\
370 / 745)\end{array}$ & $25.6 \%$ (658/745 vs. $774 / 745)$ & $\begin{array}{l}38.3 \%(29 / 745 \\
\text { vs. } 47 / 745)\end{array}$ & [49] \\
\hline \multirow{5}{*}{$\begin{array}{l}\text { Mozambique } \\
\text { (Illha Josina) } \\
\text { Cohort } 2\end{array}$} & $1-4$ years & & & $0-4$ months & $\begin{array}{l}51.1 \%(111 / 189 \text { vs. } \\
147 / 178)\end{array}$ & $61 \%(21 / 189$ vs. $40 / 178)$ & NR & NR & {$[48,44]$} \\
\hline & & & & $0-6$ months & $45 \%(157 / 189$ vs. $166 / 178)$ & $35.4 \%$ (46/189 vs. $56 / 178)$ & $30 \%$ (52/189 vs. $68 / 178$ ) & & \\
\hline & & & & $\begin{array}{l}8.5-18.5 \\
\text { months }\end{array}$ & NR & $9 \%(60 / 181$ vs. $59 / 171)$ & NR & & \\
\hline & & & & $0-18.5$ months & NS ( $50 / 160$ vs. $49 / 160)$ & NR & & & \\
\hline & & & & $0-21$ months & & $9.3 \%$ (72/209 vs. $76 / 208)$ & NR & NS (6/209 vs. $6 / 208$ ) & [47,49] \\
\hline \multirow[t]{2}{*}{$\begin{array}{l}\text { Mozambique } \\
\text { (Ilha Josina \& } \\
\text { Taninga) }\end{array}$} & $8-10$ weeks & AS02D & $\begin{array}{l}10 / 14 / 18 \text { weeks of age } \\
(25 \mu \mathrm{g} / 0.5 \mathrm{ml})\end{array}$ & $0-3$ months & $65.9 \%(22 / 93$ vs. $46 / 92)$ & $65.8 \%$ (9/93 vs. $22 / 92)$ & & & [50] \\
\hline & & & & $0-6$ months & NS & $35.5 \%$ & & & \\
\hline \multirow[t]{2}{*}{ Tanzania } & & & $\begin{array}{l}8 / 12 / 16 \text { weeks of age } \\
25 \mu \mathrm{g} / 0.5 \mathrm{ml}\end{array}$ & $\begin{array}{l}0-6 \text { months } \\
0-10 \text { months }\end{array}$ & $65.2 \%$ (8/146 vs. $20 / 151)$ & $43.2 \%$ (7/146 vs. $11 / 151)$ & & & [51] \\
\hline & & & & & & $41.8 \%$ & & & \\
\hline \multirow[t]{2}{*}{$\begin{array}{l}\text { Kenya \& } \\
\text { Tanzania }\end{array}$} & 5-17 months & AS01E & $\begin{array}{l}0 / 1 / 2 \text { months } \\
(50 \mu \mathrm{g} / 0.5 \mathrm{ml})\end{array}$ & $0-8$ months & $\begin{array}{l}\text { Prevalence parasitemia } 2 \% \\
\text { vs. } 3 \%\end{array}$ & $53 \%$ (32/402 vs. $66 / 407)$ & $56 \%(38 / 402$ vs. $86 / 407)$ & NR & [52] \\
\hline & & & & $0-10.5$ months & & $49 \%$ ( $42 / 447$ vs. $78 / 447)$ & $54 \%$ (49/447 vs. $109 / 447$ ) & & \\
\hline
\end{tabular}

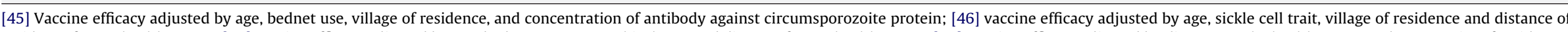

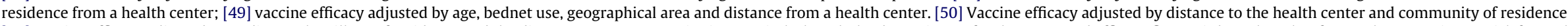

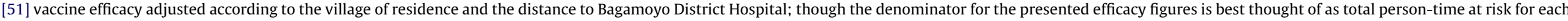

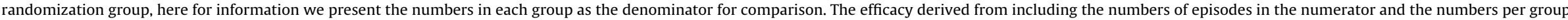

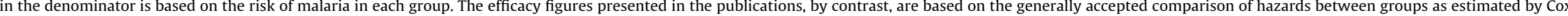
proportional hazards regression models. 
mice with RTS,S/AS01B did not increase the titer of CS antibodies as compared to RTS,S/AS02A, but it did increase the frequency of CD4 T and CD8 T cells specific for the CS protein. Immunization of monkeys with RTS,S/AS01B also increased the CD4 T cells responses but it did not induce detectable levels of CD8 T cells $[26,27]$.

To this day, no clinical trials have been conducted to address the protective efficacy of recombinant PfCSP protein in AS02, AS02A or AS01B with that of adjuvanted RTS,S. Thus, the contribution of the virus-like structure of RTS,S as a delivery vehicle for the CS protein still needs to be determined.

\section{Protective efficacy of RTS,S in malaria-naïve volunteers}

The establishment of the malaria sporozoite mosquito-bite challenge model at WRAIR/NMRC using the 3D7 clone of the NF54 isolate of $P$. falciparum has been an essential feature of the RTS,S development program, allowed the testing of a variety of formulations of RTS,S in a controlled setting establishing safety and protective efficacy before venturing into the field. The experimental malaria challenge of human volunteers is safe and highly reproducible in terms of incubation times and pre-patent period (the time elapsed from the sporozoite challenge and detection of blood stage parasites) [28].

A summary of the clinical trials using RTS,S in malaria-naïve volunteers is shown in Table 1 . The first trials conducted by Gordon and Stoute at WRAIR were aimed at assessing safety and protective efficacy of RTS,S formulated either in AS04, AS03, or AS02 in homologous prime-boost immunization regimens[19,29]. All formulations were found to be safe and well tolerated, despite some reactogenicity at the site of injection. RTS,S formulated in adjuvant ASO2 proved to be the most powerful vaccine, protecting $85.7 \%$ (6/7) of volunteers against sporozoite challenge, compared to $25-28.5 \%$ protection in the RTS,A/AS03 group, and $0-12.5 \%$ in the RTS,S/AS04 group, though with the small sample size the $95 \%$ confidence intervals were very wide. The high level of protection seen in the RTS,S/AS02 group was attributed to the MPL and QS21 immunostimulants in the adjuvant.

Further trials were conducted to determine the optimal dose of RTS,S vaccine and immunization regimens $(1,2$ or 3 immunizations) [30]. Three doses of $25 \mu \mathrm{g}$ given at various intervals (either $0,1,3$ months or $0,1,9$ months) were found to be optimal, as they protected about half of the volunteers (45-57.1\%, Table 1 ). The level of protection conferred by RTS,S/AS02 was however lower than that observed in Stoute's trial (85.7\%) [29]. It is noteworthy to mention that during the Stoute trial, the dose for the last (3rd) immunization was reduced to a 5 th, in view of the systemic adverse events developed by 1 of the volunteers. This immunization regimen was not further tested in humans and the immunogenicity of RTS,S/ASO2 under this specific regimen has not been addressed in animal models. It thus leaves an open question of whether reducing the last dose of the vaccine may account for greater protection.

In order to prevent degradation, RTS,S was reformulated from a liquid form to a lyophilized form (to be reconstituted in the adjuvant prior to immunization), and the preservative thimerosal of the AS02 adjuvant was replaced by lactose (AS02A). A new set of clinical trials conducted at WRAIR tested the protective efficacy of the new formulations [31-33], and protection was slightly lower (32\%) than that with the former vaccines (50-57\%), though such effect may be attributed to the small sample sizes. Furthermore, RTS,S formulated in the new AS01B adjuvant (based on liposomes containing MPL and QS21) protected a higher percentage of malaria-naïve volunteers than when formulated in ASO2A, (50\% vs. 32\%), though the statistical significance was poor $(p=0.11$, Table 1$)$ [33]. Some of the protected volunteers by RTS,S/AS02A or RTS,S/AS01B were rechal- lenged 5-6 months later, and about half of them were still protected $[33,34]$ indicating that RTS,S vaccination could induce long-term memory responses.

Heterologous prime-boost combination regimens (meaning the use of different vaccine platforms for priming and boosting) have long been envisioned as a strategy to increase the immunogenicity and protective efficacy of malaria vaccines in general, and RTS,S in particular. The rationale behind this strategy is simple: if a particular vaccine platform is efficient in eliciting humoral but not cellular responses and another vaccine platform does the opposite, in combining both vaccine platforms one would expect to stimulate the various effector arms of the immune system synergistically, i.e, antibodies, CD4 and CD8 T cells, thereby preventing infection more effectively. RTS,S is a good platform for eliciting antibodies and to a lesser extent CD4 T cells, but in most cases has failed to induce detectable cytotoxic CD8 T cell responses (Table 3 ), and is thus a candidate for prime-boost regimens that could strengthen CD8+ T cell responses.

There is good evidence that heterologous prime-boost approach works. For example, we showed that immunization of rhesus macaques with DNA expressing P. knowlesi (Pk) liver and blood stage antigens (CSP, SSP2/TRAP, AMA1, and MSP1), followed by a boost with poxvirus expressing the same genes, protected several animals against challenge with infectious Pk sporozoites, whereas monkeys immunized with the recombinant poxvirus alone were not protected [35]. Furthermore, immunization of rhesus macaques with human adenovirus serotype 35 (Ad35) encoding for PfCSP followed by boosting with RTS,S/AS01B increased the CD4 T cell response to CS protein [36]. Similar results were obtained when macaques were primed with DNA encoding PfCSP followed by boosting with RTS,S/AS02A [37]. In humans, immunization with DNA encoding for PfCSP followed by a boost with RTS,S/AS02A also increased the CD4 and CD8 T cell responses to CS protein [38]. However, the protective efficacy of this approach is unknown, since the immunized volunteers were never challenged.

Dunachie and co-workers at the University of Oxford tested the protective efficacy of RTS,S/AS02A in heterologous prime-boost immunization regimens with a modified vaccinia virus Ankara (MVA) expressing full-length PfCSP (MV-CS) [39]. MVA does not replicate in the infected human cells but it is able to express the recombinant malaria antigen. Priming with MVA followed by 2 doses of RTS,S/ASO2 or the reverse order increased the T cell response against CS protein (Table 3 ) but surprisingly, did not increase the level of protection as compared to RTS,S/AS02A alone in a small study (Table 2). The same group also showed that a heterologous prime-boost combination using DNA and MVA encoding for PfCSP did not confer protection, whereas the same immunization regimen, using TRAP instead of CS protein as the nominal malarial antigen, protected one out of 8 volunteers [40]. Prime-boost immunization regimens using attenuated fowlpox and MVA viruses encoding for PfCSP also showed no evidence of significant protection against sporozoite challenge [41].

In all the RTS,S trials, it was commonly found that vaccinated but non-protected volunteers experienced a significant delay in the pre-patent period (Table 1). Based on the parasite's life cycle (Fig. 1) the pre-patent period as detected by microscopy reflects, on the one hand, the number of sporozoites able to infect the liver (approximately 10 to several hundred sporozoites are delivered by a mosquito) and the number of liver-stage merozoites released from the infected hepatocytes (approximately 20,000-40,000 merozoites per infected hepatocyte) [42], and on the other hand, the rate of growth of parasites in the blood. Since RTS,S should not directly affect the growth rate in the blood, an extended pre-patent period, as observed in these volunteers, strongly suggested that RTS,S vaccination elicited an effective immune response that was 
Table 3

In vitro $\mathrm{T}$ cell responses in malaria-protected vs. unprotected subjects.

\begin{tabular}{|c|c|c|c|c|c|c|c|c|}
\hline Assay & Vaccine groups & Time of assay & Sample (no. cells) & Antigen added (concentration) & Costimulation provided & Stimulation time & Protected vs. unprotected & Ref \\
\hline \multirow[t]{6}{*}{$\mathrm{T}$ cell proliferation } & RTS,S/AS02A & 2 weeks after last dose & $\operatorname{PBMC}\left(2 \times 10^{6} / \mathrm{ml}\right)$ & $\begin{array}{l}\text { RTS,S }(10 \mu \mathrm{g} / \mathrm{ml}) \text {, or CS protein-derived } \\
\text { peptides p2, p5, p34, p35, p36, p37, } \\
\text { p45 }(30 \mu \mathrm{g} / \mathrm{ml})\end{array}$ & No & 5 days & NS & [31] \\
\hline & RTS,S/ASO2 & 2 weeks after last dose & $\operatorname{PBMC}\left(2 \times 10^{6} / \mathrm{ml}\right)$ & $\begin{array}{l}\text { RTS,S }(10 \mu \mathrm{g} / \mathrm{ml}) \text {, or either } \mathrm{p} 2, \mathrm{p} 5 \\
\text { peptides }(20 \mu \mathrm{g} / \mathrm{ml})\end{array}$ & No & 5.5 days & NS & [32] \\
\hline & RTS,S/AS02 & 2 weeks after last dose & $\operatorname{PBMC}\left(2 \times 10^{6} / \mathrm{ml}\right)$ & $\mathrm{RTS}, \mathrm{S}(0.3,3$, or $30 \mu \mathrm{g} / \mathrm{ml})$ & No & & NS & [30] \\
\hline & RTS,S/AS04 & 2 weeks after last dose & PBMC (NR) & Overlapping 11-mer CSP C-terminus & NR & 7 days & NS & [29] \\
\hline & RTS,S/AS03 & & & peptides & & & & \\
\hline & RTS,S/AS02 & & & & & & & \\
\hline \multirow[t]{4}{*}{ ICS } & $\begin{array}{l}\text { RTS,S/AS02A } \\
\text { RTS,SAS01B }\end{array}$ & 2 weeks after last dose & $\operatorname{PBMC}\left(2 \times 10^{7} / \mathrm{ml}\right)$ & $\begin{array}{l}\text { Overlapping } 11 \text {-mer CSP C-terminus } \\
\text { peptides }(2.5 \mu \mathrm{g} / \mathrm{ml})\end{array}$ & CD28/CD49d Abs & $20 \mathrm{~h}$ & $\begin{array}{l}\text { dsCD4 T cells }=963 / 10^{6} \text { vs. } 308 / 10^{6} \\
(p<0.001)\end{array}$ & [33] \\
\hline & RTS,S/ASO4 & 2 weeks after last dose & $\operatorname{PBMC}\left(5 \times 10^{6} / \mathrm{ml}\right)$ & p34, p35, p36, p37, p39 peptides & rIL-2 + rIL-7 & $11-15$ days & CD4 IFN $\gamma=0.20 \%$ vs. $0.066 \%(p=0.042)$ & [67] \\
\hline & $\begin{array}{l}\text { RTS,S/AS03 } \\
\text { RTS,S/AS02 }\end{array}$ & & & $(20 \mu \mathrm{g} / \mathrm{ml})$ & & & CD8 IFN $\gamma=0.33 \%$ vs. $0.11 \%(p=0.009)$ & \\
\hline & RTS,S/ASO2D & 10.5 weeks after last dose & Whole blood $(80 \mu \mathrm{l})$ & $\begin{array}{l}\text { Overlapping } 15 \text {-mer CSP C-terminus } \\
\text { peptides }(1.25 \mu \mathrm{g} / \mathrm{ml})\end{array}$ & CD28/CD49d Abs & $42 \mathrm{~h}$ & $\begin{array}{l}\text { CD8 IFNg }=1.398 \% \text { vs. } 1.121 \% \\
(p=0.074) ; \text { CD4 IL2: NS }\end{array}$ & [68] \\
\hline \multirow[t]{5}{*}{ ELISPOT } & $\begin{array}{l}\text { RTS,S/AS02A } \\
\text { RTS,SAS01B }\end{array}$ & 2 weeks after last dose & $\operatorname{PBMC}\left(2 \times 10^{6} / \mathrm{ml}\right)$ & $\begin{array}{l}\text { Overlapping } 11 \text {-mer CSP C-terminus } \\
\text { peptides }(2.5 \mu \mathrm{g} / \mathrm{ml}) \\
\text { p2, p4 peptides }(40 \mu \mathrm{g} / \mathrm{ml})\end{array}$ & No & $24 \mathrm{~h}$ & $\begin{array}{l}\text { IFN } \gamma=212 \text { vs. } 96 \mathrm{spm}(p<0.001) \\
\text { IL- } 2=53.5 \text { vs. } 20 \mathrm{spm}(p<0.002) \\
\text { IFN } \gamma=61 \text { vs. } 20 \mathrm{spm}(p<0.002)\end{array}$ & [33] \\
\hline & $\mathrm{RTS}, \mathrm{S} / \mathrm{ASO} 2$ & 2 weeks after last dose & $\operatorname{PBMC}\left(3 \times 10^{6} / \mathrm{ml}\right)$ & $\begin{array}{l}\text { RTS, }(10 \mu \mathrm{g} / \mathrm{ml}), \mathrm{p} 2, \mathrm{p} 4 \text {, or p5 } \\
\text { peptides }(2 \mu \mathrm{g} / \mathrm{ml})\end{array}$ & No & $44 \mathrm{~h}$ & IFN $\gamma=$ NS & [32] \\
\hline & MRR RRM & 1 weeks after last dose & $\operatorname{PBMC}\left(4 \times 10^{5}\right)$ & CSP peptides $(25 \mu \mathrm{g} / \mathrm{ml})$ & No & $18 \mathrm{~h}$ & IFN $\gamma=$ NS (119 vs. $310 \mathrm{spm})$ & [39] \\
\hline & RTS,S/AS02 & 2 weeks after last dose & $\operatorname{PBMC}\left(2 \times 10^{6} / \mathrm{ml}\right)$ & $\begin{array}{l}\text { P34, p35, p36, p37, p47, or p50 } \\
\text { peptides }(20 \mu \mathrm{g} / \mathrm{ml})\end{array}$ & No & 12 days & $\mathrm{IFN} \gamma=\mathrm{NS}$ & [32] \\
\hline & $\begin{array}{l}\text { RTS,S/AS04 } \\
\text { RTS,S/AS03 }\end{array}$ & 2 weeks after last dose & $\operatorname{PBMC}\left(2 \times 10^{6} / \mathrm{ml}\right)$ & $\begin{array}{l}\text { P34, p35, p36, p37, } \mathrm{p} 39 \text { peptides } \\
(20 \mu \mathrm{g} / \mathrm{ml})\end{array}$ & rIL-2 + rIL-7 & $11-15$ days & INF $\gamma=263$ vs. $15 \mathrm{spm}(p=0.001)$ & [67] \\
\hline \multirow{4}{*}{$\begin{array}{l}\text { Cytokine secretion } \\
\text { (ELISA) }\end{array}$} & $\begin{array}{l}\text { RTS,S/AS02 } \\
\text { RTS,S/AS04 }\end{array}$ & 2 weeks after last dose & PBMC (NR) & CSP C-terminus peptides & NR & 4 days & IFN $\gamma=\mathrm{NS}$ & [29] \\
\hline & $\mathrm{RTS}, \mathrm{S} / \mathrm{ASO} 3$ & & & & & & & \\
\hline & RTS,S/AS02 & & & & & & & \\
\hline & RTS,S/AS02D & 10.5 weeks after last dose & Whole blood $(80 \mu \mathrm{l})$ & $\begin{array}{l}\text { Overlapping } 15 \text {-mer CSP C-terminus } \\
\text { peptides }(1.25 \mu \mathrm{g} / \mathrm{ml})\end{array}$ & CD28/CD49d Abs & $42 \mathrm{~h}$ & $\begin{array}{l}\text { IL- } 2 \text { detected in } 31.5 \% \text { vs. } 5.9 \% \text { subjects } \\
(p=0.053) \text { IFN } \gamma=\text { NS IL- } 4=\text { NS }\end{array}$ & [68] \\
\hline \multirow[t]{2}{*}{ CTL assay } & RTS,S/AS04 & 2 weeks after last dose & PBMC (NR) & Overlapping 11-mer CSP C-terminus & NR & 7-14 days & Undetectable levels & [29] \\
\hline & $\begin{array}{l}\text { RTS,S/AS03 } \\
\text { RTS,S/AS02 }\end{array}$ & & & peptides (NR) & & & & \\
\hline
\end{tabular}


able to reduce the burden of liver stage parasites, though it did not suffice to confer protection in every instance. This was further confirmed by investigators at Oxford [42] who used quantitative PCR to demonstrate that the liver-to-blood inocula in the vaccinated volunteers was significantly lower than that in non-vaccinated volunteers.

In summary, the long-term commitment and effort by investigators at WRAIR, GSK, and Oxford demonstrated that RTS,S vaccination can protect a significant number of malaria-naïve volunteers against mosquito challenge by eliciting protective immune responses against the CS protein, and that heterologous prime-boost combination regimes using poxvirus as the partner to RTS,S did not increase the vaccine's efficacy.

\section{Protective efficacy of RTS,S in field trials}

In the trials described above, testing RTS,S for prevention of malaria was straightforward since the volunteers were malaria-naïve and the mosquito-bite challenge was performed simultaneously in all volunteers and was thus well controlled. Testing a partially effective vaccine in malaria-endemic areas is not as simple, since natural exposure to the parasite is common and uncontrolled in terms of its timing, strain, dose and frequency, and additional factors such as age and acquisition of natural immunity may differentially affect the outcome among volunteers. Therefore, field trials require larger populations, longer study periods, and a higher cost. In addition, the choice of endpoints is less clear. In the experimental sporozoite challenge trials, volunteers are followed up actively with daily blood smears and treated at the earliest onset of parasitemia as detected by light microscopy, limiting efficacy measurements to sterile protection or delay in parasitemia (partial protection) relative to infectivity controls. In contrast, field trials allow an array of potential clinical endpoints in addition to parasitemia. For example, passive case detection may be used to determine vaccine efficacy against clinical malaria (defined as fever and parasitemia) or severe malaria (associated with life-threatening symptoms such as anemia, prostration or altered consciousness). These less frequent outcomes augment the required sample size and the complexity of the trial. Still another complication is the potential need (depending on the objectives of the trial) to treat subjects with anti-malarial drugs to clear patent infection before administering the 3rd dose of the vaccine.

This greater complexity brings with it the opportunity to measure important public health endpoints under realistic field conditions. End points that estimate vaccine efficacy against clinical or severe disease are more relevant than those for prevention of infection, as symptomatic malaria accounts for the morbidity and mortality associated with malaria. All these factors are taken into consideration to define the most appropriate end points (Box 1), and to select the best target populations, in the design of vaccine field trials. The developers of RTS,S have taken advantage of these many possibilities to design studies assessing a range of variables, including first onset of parasitemia, multiplicity of infection, first or only (FO) clinical episode, multiple clinical episodes, and severe disease. A range of definitions for a clinical episode, distinguished among other factors by different densities of parasitemia experienced in conjunction with fever, have also been explored.

These trials are conducted against a variable back-drop of naturally acquired immunity (NAI). In general, young children are more susceptible to clinical malaria than adults, as they lack this natural immunity, which is gradually acquired following repeated infections. Natural immunity against malaria is defined as a state in which the host immune system can control and tolerate the density of blood stage parasites and their toxic effects, thereby protecting

\section{Box 1: A perspective on calculating efficacy in field tri-} als.

The vaccine efficacy estimates for RTS, $S$ in field studies are calculated as time-to-event analyses (TTE), which examine rates of predefined endpoints including first malaria infections and first episodes of clinical malaria in relation to total personyears at risk. Vaccine efficacy is estimated from hazard ratios using Cox regression models. TTE analyses such as those used for RTS,S field trials have formed part of accepted regulatory submissions by several regulatory authorities including the FDA and were felt to be appropriate measures of malaria vaccine efficacy in two WHO consultations, though work on optimum measures of malaria vaccine efficacy continues [79]. TTE methods are able to account for variable follow-up times between individuals, which are the norm in field trials due to rolling enrollment and loss to follow-up. In addition, the use of the Cox regression methodology in conducting such analyses allows adjustment for covariates such as age that could otherwise potentially bias vaccine efficacy estimates.

While TTE analysis provides an accurate and balanced assessment of vaccine effect, its results are not intuitive for non-statisticians, requiring careful interpretation. The initial Mozambique study provides a good example. The children vaccinated with RTS,S in Cohort 2 experienced an estimated $45 \%$ reduction in the rate of first infection by TTE analysis [47], but as the vaccine did not confer complete protection at the transmission intensities experienced (E.I.R. at the study site was estimated to be 38 infective bites/year in 2002), most of the children eventually experienced at least 1 infection by the end of the 6 months observation period. This constituted approximately $93 \%$ of children in the control group and $83 \%$ in the RTS,S/AS02A group (166/178 and 157/189, respectively, where the numerators are the numbers of children infected during the 6 months observation period and the denominators are the numbers of children completing immunization in each group and entering the observation period-thus not adjusted for subsequent drop-outs). Thus it would be incorrect to say that RTS,S prevented $45 \%$ of recipients from becoming infected, a percentage that is considerably lower. Rather, a reasonable interpretation is that the rate for first infections was reduced by $45 \%$.

With this understanding, in our view available data indicate that RTS,S acts as a leaky rather than an all-or-nothing vaccine, conferring partial protection to all or most vaccinees rather than complete protection to some [80]. For many, this is an unfamiliar concept, when compared, for example, to all-ornothing vaccines, which can be easily understood in terms of their relevance at the individual level. Efficacy calculated as a reduction in the proportion of individuals becoming infected over a given time period, such as is commonly done with highly efficacious all-or-nothing vaccines, gives each vaccine recipient a clear sense of how the vaccine diminishes his or her personal risk. In contract, leaky vaccines are easier to understand when considering impact at community levels.

In the Mozambique example, consider the TTE efficacy estimate of $45 \%$ against first infection over 6 months of follow-up in Cohort 2 and the TTE efficacy estimate of $35 \%$ against first episode of clinical malaria and a $49 \%$ against severe malaria in Cohort 1. This level of protection could indeed translate into significant community-wide reductions in malaria-related morbidity, particularly if these efficacy data extend to rates of all episodes of malaria rather than just first episode data. These efficacy calculations indicate that if RTS,S were to be deployed as part of the Expanded Program on Immunization (EPI), benefits could include reductions in the number of clinic visits, treatment administrations, days lost from school, hospitalizations and other malaria-related public health indices. Since most children who die from malaria experience severe disease prior to death, the findings in Mozambique and also in more recent trials, of reduced rates of severe disease, imply that RTS,S administered in an appropriately designed large 
study could also be shown to reduce malaria-related or allcause mortality. The current Phase 3 study should better define the overall public health impact of RTS,S.

against clinical disease. However, naturally immune individuals are unable to completely clear parasitemia and they are susceptible to new infections when parasitemia is cleared with anti-malarial drugs [43]. NAI also wanes in time when subjects relocate out of malaria-endemic areas for prolonged periods, and they become again susceptible to clinical disease upon re-infection. NAI is generally well developed in older children and adult subjects living in endemic areas after years of continuous exposure to the parasite and repetitive episodes of clinical malaria but is absent in infants and young children. A degree of natural immunity may be also afforded by maternal antibodies in newborns.

Field trials need to employ a complex statistical analysis to adjust the vaccine efficacy to many variables with potential masking effects such as the effects of age and NAI, the use of bednets to prevent mosquito bites, distance from the village to the health center during follow-up, titers of pre-existent malaria antibodies, and genetic traits that may protect against clinical disease, such as sickle cell trait. The statistical analyses of these large trials is also complicated by the fact that volunteers reach end points differentially in time and may need periods during their follow-up adjusted [censored] for statistical purposes, if, for example, they are treated for malaria and then further followed for recurrent episodes. Due to these considerations, vaccine efficacy is best calculated according to time-to-event statistical analysis, which provides an optimal measure of efficacy for a partially effective vaccine tested in the field (an example is shown in Fig. 3 [44]). The use of the Cox regression methodology in conducting such analyses allows adjustment for above variables that could potentially influence vaccine efficacy estimates in such trials (Box 1).

Due to longer periods of follow-up, volunteers in field trials often cannot comply strictly with the protocol, or may discontinue participation at any point. Thus, the "according-to-protocol" (ATP) analysis considers only results from the subjects that have fully complied with the protocol guidelines from the beginning to the end of a study. Intention-to-treat analysis (ITT) takes into account the results from all the enrolled subjects, whether or not they complied or withdrew from the study. Both have been considered in the field trials of RTS,S.

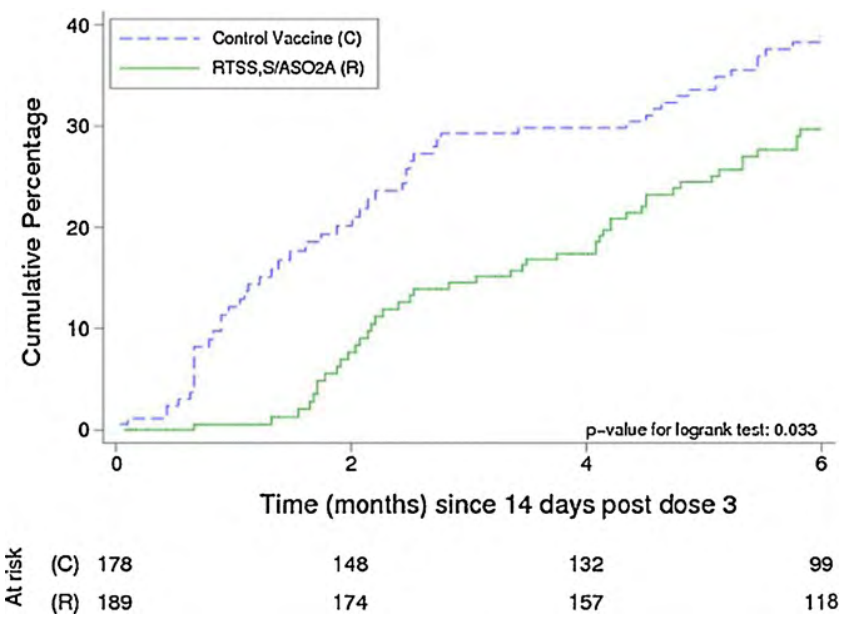

Fig. 3. Kaplan-Meier survival curves for the cumulative proportion with at least one episode of clinical malaria during the double-blind and single-blind phases in cohort 2 , respectively (ATP cohort) ${ }^{40}$.

\subsection{Efficacy recorded in field trials}

After initial safety studies, vaccination with RTS,S formulated in AS02 was first shown to prevent malaria infection in adult volunteers living in The Gambia over a period of 6 months (vaccine efficacy 34\%) [45]. Prevention of infection was high during the first 9 weeks (vaccine efficacy 71\%) but waned during the next 6 weeks (vaccine efficacy $0 \%$ ). A second efficacy trial was initiated in Kenya to test the protective efficacy of RTS,S formulated in AS02A or AS01B [46]. Interestingly, when vaccine efficacy was adjusted to co-variables such as age, sickle cell train, village of residence and distance of residence from a health center, RTS,S/AS02A was shown to be more efficacious than RTS,S/AS01B in preventing infection during a period of 6 months (34\% vs. 11\%). The lower protective efficacy of RTS,S/AS01B as compared to RTS,S/AS02A was not in agreement with the results from the WRAIR trial using malarianaïve volunteers (Table 1 ). The unadjusted (crude) vaccine efficacy was however similar for RTS,S/AS02A and RTS,S/AS01B in the Kenya study (vaccine efficacy 31.7 and $29.5 \%$, respectively).

The group led by Pedro Alonso in Spain initiated a trial in Mozambique to assess the vaccine efficacy of RTS,S/AS02A in children aged 1-4 years. The protocol had 2 arms. One was designed to determine vaccine efficacy against infection (cohort 2). This arm enrolled children living in a higher transmission area for malaria (Illha Josina), to make the end point easier to address. The children under this cohort were treated with anti-malarial drugs to clear infection prior to the 3rd dose of vaccine. The 2nd arm (cohort 1) was designed to address vaccine efficacy against clinical and severe disease, and for this arm children were enrolled from a lower malaria-transmission area (Manhica). Cohort 1 required recruiting a much larger number of children, and they were not treated with anti-malarial drugs.

The results from the cohort 2 indicated that RTS,S/ASO2A vaccination was effective in reducing the rate of infection over a 6 months observation period (vaccine efficacy $45 \%$ according to time to event analysis). Interestingly enough, vaccination was also effective against the development of clinical disease (vaccine efficacy against the first or only episode (FO) was 35.4\% and for all clinical episodes was 30\%) during the initial observation, but the antidisease efficacy waned over time $[44,47,48]$. By contrast, protection against clinical and severe disease in the cohort 1 lasted 45 months. In cohort 1, the vaccine efficacy for FO, for all clinical episodes, and for severe malaria was $30.5,25.6$ and $38.3 \%$, respectively, over the 45-month study [47-49]. The results from these 2 trials in areas with different malaria transmission intensity strongly suggested that RTS,S may be more efficacious in low-malaria-transmission areas than in the high-transmission areas.

In the Mozambique studies, there were no differences in the parasite density at first clinical episode between vaccinated and control children. The immunological analyses conducted on this trial have also not provided information to help explain the underlying mechanisms of protection (Table 3). Thus, the question remains: how can a vaccine that targets sporozoites and liver stage parasites only, in a population that mostly lacks natural immunity against the blood stage parasites, reduce the rate of clinical and severe disease?

Using the $P$. berghei rodent model, Rodriguez's group at NYU has observed that the number of parasites released from the liver is critical for dictating progression of mice toward cerebral malaria, even though mice developing or not developing cerebral malaria achieved similar levels of blood stage parasitemia (personal communication). These pre-clinical data support the ameliorating effect of RTS,S vaccination on clinical/severe disease, but the underlying mechanisms are still unknown.

Additional trials were conducted in areas of Tanzania where malaria transmission is perennial and in Mozambique in the 
higher transmission area where cohort 2 was recruited to determine the vaccine efficacy of RTS,S adjuvanted in AS02A (termed AS02D for pediatric formulation) in 2-3 month-old babies with no prior malaria treatment (Table 2) [50,51]. In the Mozambican babies, RTS,S vaccination conferred protection against infection for a period of 3 months (vaccine efficacy 65.9\%), but protection completely waned at the end of the 6 months follow-up period. In contrast, RTS,S protected against infection a significant number of infants in Tanzania for a full period of 6 months (vaccine efficacy 65.2\%). In both trials, RTS,S was shown to confer protection against clinical disease (vaccine efficacy 35.5 and $41.8 \%$, respectively), and interestingly enough, the protection against clinical disease did not wane over a period of 6-10 months.

Finally, RTS,S formulated in the new adjuvant AS01B (termed AS01E for pediatric formulation) has also been tested in infants (5-17 months of age) in Kenya and Tanzania [52]. Protection against FO and all clinical episodes was slightly higher than for the earlier Tanzania trial using AS02D adjuvant, and lasted for 10.5 months (Table 2). The superiority of RTS,S/AS01E as compared to RTS,S/AS02D is appealing for immunization programs hoping to target infants with a malaria vaccine.

In all these trials, RTS,S proved to be an excellent vaccine against hepatitis B, since the titers of HBsAg antibodies elicited upon vaccination reached a protective level. In some of the pediatric trials, RTS,S was included or alternatively staggered within the Expanded Program on Immunization (EPI), which includes diphtheria, tetanus and pertussis vaccine (DPT) with Haemophilus influenza type b conjugate vaccine $[50,51,53]$. Interestingly, RTS,S did not alter the seroconversion rates of the EPI vaccines, though the titers were reduced in co-administration. The results were welcome since RTS,S can be thus incorporated into the EPI, which will reduce the cost and lower the logistic efforts for vaccination, assuming that RTS,S will be licensed.

The initial Phase 2b studies indicate that RTS,S can protect specific populations of vulnerable malaria victims (infants and children). In May 2009, a group of 11 African research centers partnered with GSK and PATH-MVI to initiate a large, multicenter Phase 3 trial, which is expected to enroll up to 16,000 infants and children from 7 countries across the sub-Saharan Africa. The study will assess protective efficacy under a variety of malaria transmission intensities. Trials to test RTS,S in another vulnerable population namely pregnant women, have not been yet initiated.

Long-term observation of the volunteers in the Phase $2 \mathrm{~b}$ pediatric trials continues and more data will be soon be available to determine the long-term efficacy of RTS,S against symptomatic malaria. These studies, together with long-term follow-up from the Phase 3 trial, will address theoretical concerns on whether vaccination of infants in malaria-endemic areas can alter the epidemiology of the disease by shifting the incidence of clinical/severe malaria from very young children to older children and adults [54]. Additionally, some data are available, with additional data expected in the future, to address concerns regarding the possibility that RTS,S vaccination could promote the emergence of $P$. falciparum parasite strains carrying polymorphisms in the C-terminus region of CS protein (the CS protein C-terminus portion of RTS,S is derived from NF54 strain). Sequencing of the CS gene from parasites isolated from infections occurring in adult vaccinees and controls in the The Gambia trial $[45,55]$ and in children in the Mozambique trial [56] showed no increase in the frequency of genetically variant parasites in the vaccinated group. This indicated that protection conferred by RTS,S is not strain-specific.

\section{The immunology of RTS,S}

The lack of immune correlates of protection in malaria has tremendously slowed the development of an efficient malaria vac- cine, though RTS,S has been able to progress successfully without an established surrogate marker. It might have been expected that the high-level protection afforded by the radiation-attenuated sporozoite model would have led to the identification of immunological correlates. However, despite the passage of nearly 50 years since its discovery by Nussenzweig and co-workers, the model has provided little definitive information, particularly in the case of humans. We do know that immunization with irradiated sporozoites elicits poor antibody responses to the CS protein, but elicits good specific cellular responses [57]. Still when it comes to testing this approach, one cannot predict which animals or humans will be protected. The failure of the irradiated sporozoite model to decipher immune correlates for protection has been attributed to the myriad of antigens expressed by the sporozoites and liver stage parasites, and it has been argued that some of these antigens are likely immunodominant and able to elicit the protective immune responses. As consequence, "antigen discovery" has become as an important field of research for malaria vaccine researchers, with the expectation that identification of the protective proteins will establish immune correlates for protection and thereafter enable the development of a sub-unit malaria vaccine equally protective as radiation-attenuated sporozoites.

Unlike the radiation-attenuated sporozoites, RTS,S expresses CS protein as the only malarial antigen. RTS,S has been shown to confer protection in malaria-naïve volunteers and in field trials, and consequently does not conform with what is known about the irradiated sporozoite model, where CS protein may not be required for protection [58]. It was thus envisioned that immune responses to CS protein should provide immune correlates for protection, and that the numerous RTS,S trials being conducted should provide enough human samples to unravel them. However, only a partial picture has emerged to date.

\subsection{Antibody response to the CS repeats}

Results from clinical trials in adult malaria-naïve volunteers and from African field trials using children and adults indicated that RTS,S elicits strong anti-CS humoral responses to the B cell epitopes located in the central repeat (NANP) region (Fig. 4). Data illustrated in Fig. 4A refer to titers of CS repeat antibodies that were measured using a standard ELISA methodology at the WRAIR's Serology Lab, normalized against a reference serum, and expressed as $\mu \mathrm{g} / \mathrm{ml}$ [29-33,39,45,59-63]. Data illustrated in Fig. 4B refer to titers of CS repeat antibodies from field trials that were measured at GSK and expressed as ELISA optical units per ml [46,47,50-53,64,65]. Overall, the results from pediatric trials were very appealing, as they indicated that the immunogenicity of RTS,S was not negatively affected by the immaturity of the immune system at the very young age (Fig. 4A and B). It is also noteworthy, that in the field trials RTS,S seemed to be more immunogenic in children than in adults (Fig. 4). This initial observation, which may indicate a negative interference between natural acquired immunity developed by adults and RTS,S, needs further investigation. The use of RTS in liquid versus lyophilized form did not affect the immunogenicity at least when tested in field trials using semi-immune (adults) volunteers.

The studies at WRAIR also allowed to investigate the correlation between CS repeat antibodies and protection against sporozoite challenge, and demonstrated that protected volunteers had higher titers of CS repeat antibodies than the non-protected ones (Fig. 5, left plots). The cut-off for protective antibody titers was estimated as $20 \mu \mathrm{g} / \mathrm{ml}$, since retrospective analyses indicated that $51.8 \%$ of volunteers having titers higher than $20 \mu \mathrm{g} / \mathrm{ml}$ were protected as compared to $4.6 \%$ of non-protected ones [30], but in a more recent study the average CS titers for non-protected volunteers was $76 \mu \mathrm{g} / \mathrm{ml}$ [33]. Data from the field trials also supported the role of CS repeat antibodies in protection against infection (Fig. 5, 


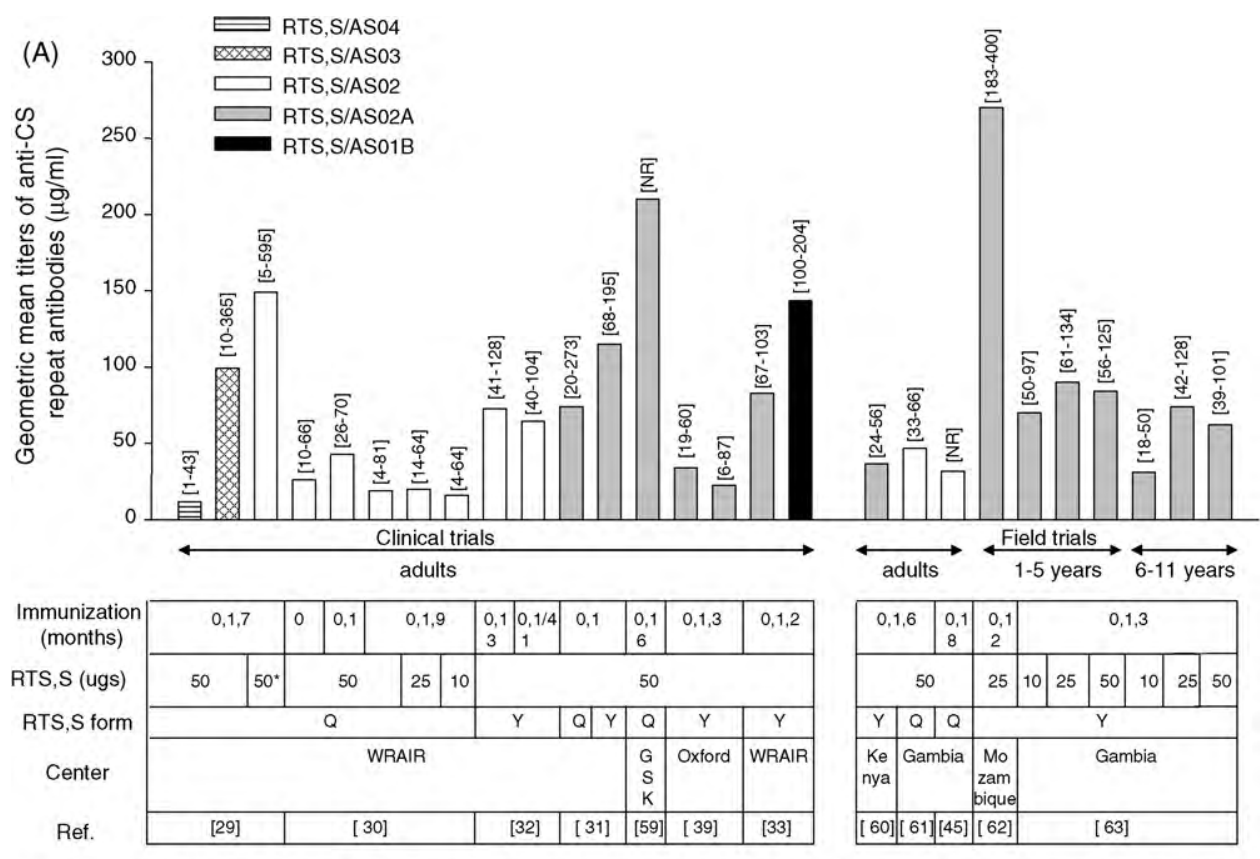

(") the last vaccine dose was reduced to 5 ug due to adverse reactions developed by one of the immunized volunteers; (Q) RTS,S liquid; ( $($ ) RTS,S lyophilized

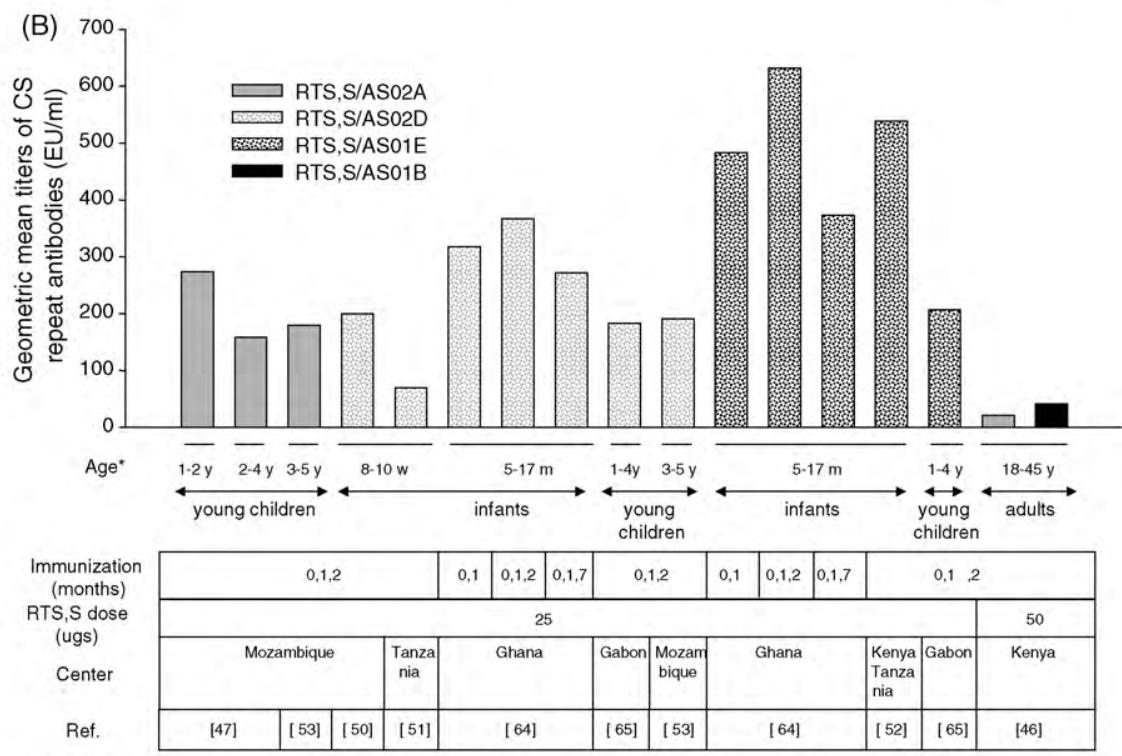

$\left({ }^{*}\right)$ age is expressed as years (y), months (m), or weeks (w). In all these trials RTS,S was used as lyphilized form.

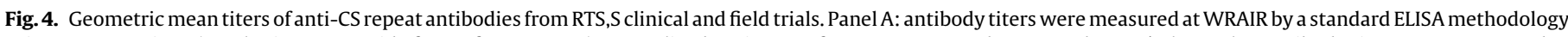

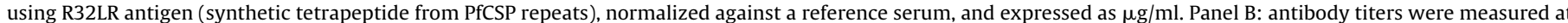

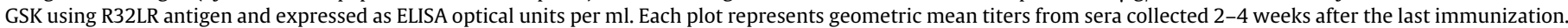
Rank values corresponding to 95\% C.I. are indicated over the plots. Specific information on each trial is shown in the table below.

right panels), though there was no correlation with prevention of clinical disease [44,52]. The CS repeat antibodies may contribute to elimination of sporozoites and infected hepatocytes by different mechanisms such as (i) cytotoxicity by activation of the complement cascade, (ii) Fc-receptor-mediated lysis by NK and NKT cells, a process also known as ADCC (antibody-dependent cell cytotoxicity), (iii) direct neutralization of live sporozoites inhibiting gliding motility and cell traversal, and (iv) Fc-receptor-mediated engulfment of sporozoites by phagocytes. Data from Krzych's group at WRAIR indicated that the CS repeat antibodies elicited by protected volunteers were able to clear live sporozoites by phagocytes [66].

Thus, the CS repeat antibodies became a close immune correlate for protection. Unfortunately the results from the Oxford trial, using a heterologous prime-boost combination with MVA-CS and RTS,S, have argued against this correlate. In the Oxford trial, the antibody response was higher in the non-protected than in the protected volunteers, though the overall titers were significantly lower than in the WRAIR and field trials (Fig. 4) [39]. A potential explanation for this difference may relate to interference of both vaccine platforms, namely MVA-CS and RTS,S, on the priming, differentiation and/or survival of B cells specific for the CS repeats. The fact that the MVA-CS/RTS,S prime-boost regimen protected volunteers to the same extent as to the RTS,S alone, but in the context of a much lower humoral response, challenges the role of antibodies as a requirement for protection against liver stage malaria infection. 


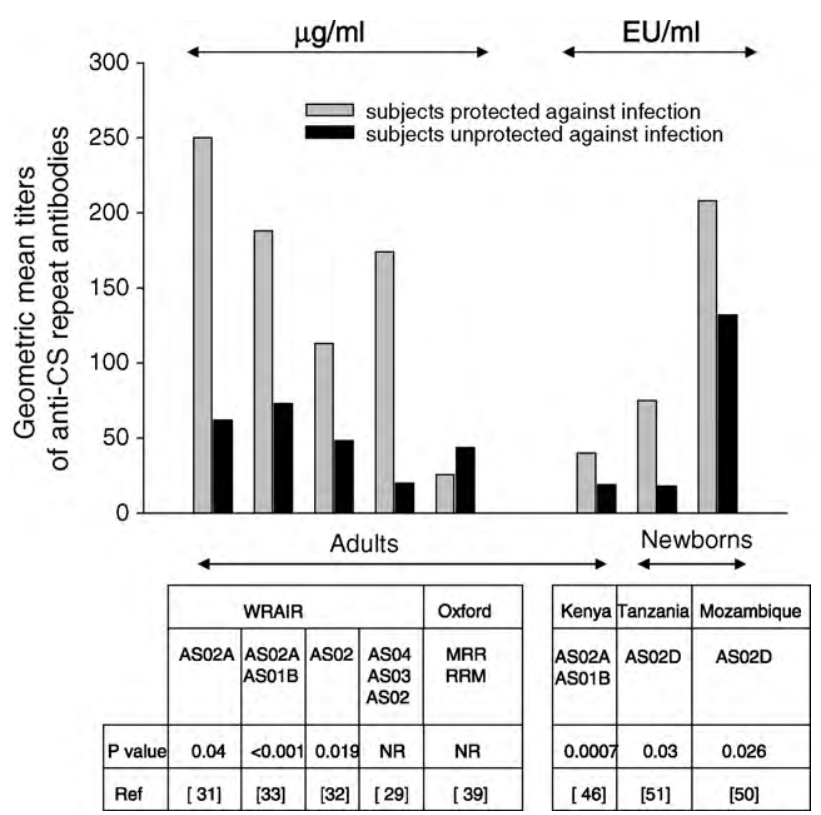

Fig. 5. Correlation between titers of anti-CS repeat antibodies and protection against infection. Geometric mean titers for antibodies to the central repeats of CS protein were calculated by ELISA using the R32LR protein as capture antigen. Antibody titers from WRAIR and Oxford trials are expressed as $\mu \mathrm{g} / \mathrm{ml}$. Antibody data from field trials are expressed as arbitrary ELISA optical units per $\mathrm{ml}(\mathrm{EU} / \mathrm{ml})$. Each plot indicates the results from independent clinical trials. The protective efficacy for each trial can be found in Tables 1 and 2, according to the reference number.

\subsection{Immune cellular responses to CS protein}

The assays aimed at quantification of $\mathrm{T}$ cell responses to CS protein have not been standardized. As a consequence, a variety of in vitro assays such as $\mathrm{T}$ cell proliferation, cytokine secretion, intracellular staining for cytokines, ELISpot, and cytotoxicity has been used. Furthermore, the conditions and timing for such assays differed among the trials. This has created some level of confusion and hampered inter-trial comparisons of the $\mathrm{T}$ cell responses elicited by RTS,S. An international workshop for standardization of T cell responses to malarial antigens was held in 2007 in London, but so far no reference laboratory has been assigned or specific $\mathrm{T}$ cell protocols delineated. Herein we will review the results of $\mathrm{T}$ cell responses from the RTS,S trials that have reported subject protection, and for which a correlation between $\mathrm{T}$ cell responses and protection has been examined.

As illustrated in Table 3, only a few trials conducted at WRAIR $[33,67]$ and a single field trial conducted in infants in Mozambique [68] have reported correlation between $\mathrm{T}$ cell responses and protection against malaria infection. The assays were based on intracellular staining (ICS) upon stimulation of PBMC (WRAIR) or whole blood (Mozambique) with CS protein-derived overlapping peptides in the presence of exogenously added $\mathrm{T}$ cell costimulation (either in the form of CD28/CD49b antibodies or recombinant IL-2 and IL-7). For some of these trials, ELISpot and quantification of cytokine secretion in supernatants also reported a correlation with malaria infection when exogenous $\mathrm{T}$ cell costimulation was provided to the cell cultures. This clearly indicates that exogenous costimulation is required for detecting in vitro $\mathrm{T}$ cell responses to the CS antigen and to discern between immune responses in protected vs. non-protected subjects.

$\mathrm{T}$ cells require 2 different signals provided by antigenpresenting cells (APC) in order to be activated. Signal one is antigen-specific and involves presentation of antigen (in the form of peptides assembled to MHC molecules) to T cells. Signal two is not antigen-specific, and involves interaction of costimulatory lig- ands expressed by activated APCs with their receptors on T cells. When $T$ cells receive signal one in the absence of signal two, they enter into a state of anergy (meaning T cell unresponsiveness to the presented antigen). This is a well-known mechanism that accounts for establishment of $\mathrm{T}$ cell tolerance to self-antigens, when autoreactive $T$ cells that have escaped thymic selection encounter antigen presented by healthy somatic cells within the tissues lacking costimulatory molecules [69]. The results of T cell assays carried out in the RTS,S trials strongly suggest that the level of T cell costimulation provided by naïve APCs in the blood (mostly B cells) does not suffice in vitro to activate $\mathrm{T}$ cells specific for CS protein, and hence there is a need to provide $\mathrm{T}$ cell costimulation exogenously to the cultures.

The T cell assays showing some level of correlation with malaria protection do not provide, however, a consensus on the type of protective (or correlative) T cell response. Protection against infection in the WRAIR trials $[33,67]$ was associated with: (i) multifunctional CD4 T cells, meaning CD4 T cells producing at the same time several inflammatory cytokines such as IL-2/INF $\gamma / \mathrm{TNF} \alpha$ as measured by ICS, (ii) secretion of INF $\gamma$ and IL-2 as measured by ELISpot and (iii) CD8 T cells producing INF $\gamma$ as measured by ICS. The studies from the Mozambique trial reported correlation of protection with CD8 $\mathrm{T}$ cells producing IFN $\gamma$ and the levels of IL-2 in cell culture supernatants, but not with CD4 T cells or IFN $\gamma$ in cell culture supernatants [68]. The situation is further complicated by the lack of correlation among results obtained by ICS, ELISpot, and cytokine secretion within the same blood samples. Thus, the effort by RTS,S investigators to disclose some level of correlation between $\mathrm{T}$ cell responses and prevention of malaria infection is meritorious, but the lack of a consensus in identifying a key $\mathrm{T}$ cell player in protection against infection is concerning and forms an impediment to further improvement of RTS,S or the development of second generation vaccines based on CS protein.

In the malaria field, it is generally believed that the correlates for protection should be "positive"-that is to say, the higher the surrogate immune marker, the higher should be the protection. However, there are recent and convincing data in humans and animal models indicating that malaria parasites can subvert the host immune system by stimulating regulatory $\mathrm{T}$ cells, which in turn down-regulate protective immune responses against malaria and facilitate infection by the parasite [70]. Regulatory T cells, such as the $\mathrm{CD}^{+} \mathrm{CD}_{25}{ }^{+} \mathrm{FOXP3}^{+}$subset (termed Tregs), are critical for maintaining self-tolerance and are endowed with powerful suppressive capabilities. Through the secretion of IL-10 and TGF $\beta$, Tregs downregulate expression of costimulatory molecules on APCs and thus induce $\mathrm{T}$ cell tolerance to the presented antigen [71]. The Tregs can also ablate the benefits of vaccination against various infectious agents such as influenza A virus, as we have observed (Surls et al. manuscript in preparation). Thus, we should consider the possibility that correlates for protection in malaria could be "negative", rather than positive. That is to say that if vaccinated subjects show stimulation of Tregs in sufficient quantities, there should not be protection, and vice versa. If this hypothesis is proven, second generation vaccines should be designed to activate specific $\mathrm{T}$ cells and at the same time to prevent activation of Tregs. This approach seems feasible since recent data indicated that boosting BCG vaccination with MVA encoding for Mycobacterium tuberculosis antigen 85A reduces the serum levels of TGF $\beta$, a cytokine required for stimulation of Treg [72].

\subsection{Gene expression profiling as immune correlates of protection}

Recent studies by the group of Ockenhouse at WRAIR [73] have demonstrated the potential of microarray gene expression technology to aid immune correlates of protection against malaria. Gene expression analysis of the blood of malaria-naïve volunteers 
immunized with adjuvanted RTS,S resulted in the identification of a group of genes involved in the proteasome pathway of antigen presentation (i.e., PSME2, PSMB9, PSMB6, and PSMA4), which were up-regulated in protected volunteers as compared to the nonprotected ones. Intracellular processing of foreign antigens through the proteasome pathway is critical for presentation of peptides in the context of MHC class I molecules and induction of cytotoxic cells. The proteasome pathway is further enhanced in the presence of IFN $\gamma$, since this cytokine induces transcriptional activation of proteins required for the formation of immunoproteasomes [74]. Results from RTS,S clinical trials in Africa using the microarray approach are highly anticipated, as they will allow us not only to determine the value of this approach for establishing an accurate immune correlate of protection but also to unravel the specific immune mechanisms underlying protection against malaria infection.

\section{Conclusions and perspectives on "second generation" malaria vaccines}

RTS,S was designed as a vaccine to prevent malaria infection, but it has proven to do something unexpected: prevent clinical and severe disease. This is a remarkable achievement, considering that prevention of disease is highly significant from the public health perspective and more immediate in its importance than prevention of infection. Special emphasis should focus on deciphering the underlying immune mechanisms involved in the protection afforded by RTS,S, as it will allow us not only to have a more comprehensive understanding of this complex infectious disease and how it is affected by this important vaccine but also to design more efficacious "second generation vaccines".

Since we have little understanding of the biology of malaria parasites, the immune evasion mechanisms that malaria parasites use to circumvent the immune system, and the protective immune responses required to combat the infection, delineating more efficacious second generation vaccines becomes very challenging. The heterologous prime-boost combination regimens, which were envisioned to act synergistically on the immune system to compensate for the deficiencies of RTS,S, have not fulfilled our expectations when tested in clinical trials. Heterologous prime-boost regimens using adenoviruses as one of the vaccine platforms may be more efficacious. Vaccine platforms containing several malarial antigens (from both liver and blood stage parasites) may prove more efficacious as they may act by eliminating both liver and blood stage parasites. Such approaches need to be experimentally tested but should also address the concern of antigen interference that might jeopardize the approach. In the rhesus monkey malaria model, we showed that SSP2/TRAP inhibited immune responses to CS protein when both antigens were given in the form of DNA [75] but such effect was overcome by a heterologous prime-boost combination using DNA and a canarypox virus expressing the 2 antigens [76]. Ongoing clinical trials at NMRC/WRAIR using DNA and Ad5 encoding for CSP and AMA- 1 and at Oxford using simian Ad and MVA, both in prime-boost combination regimens, raise high expectations for addressing the efficacy of this approach.

The results from the ongoing clinical trials at NMRC and University of Maryland using frozen irradiation-attenuated sporozoites are also highly anticipated. If the vaccine proves to be efficacious, strong logistical and strategic support will be required to transport this fragile vaccine to malaria-endemic areas. However, this should not be counted as a major flaw, if it is expected to prevent 500 million cases of symptomatic malaria and a million deaths yearly. The same applies to the genetically-attenuated sporozoite vaccine approach $[77,78]$ for which clinical trials will be shortly initiated at WRAIR.
The roadmaps for global malaria vaccine development have set specific goals for 2015 and 2025: the development of malaria vaccines able to confer 50 and $80 \%$ protection against malaria infection, respectively. RTS,S is a great development, but by itself may not be able to achieve these goals. If the above-mentioned ongoing clinical trials do not provide sufficient efficacy, the use of RTS,S in prime-boost combination with other malaria antigens and/or vaccine platforms, namely irradiated sporozoites, genetically-attenuated sporozoites, or recombinant Ad5/Ad35 may help in accomplishing these goals.

\section{Acknowledgements}

We gratefully acknowledge PLOS ONE for allowing us to republish Fig. 3. We are also most appreciative of the assistance provided by Vasee Moorthy and Ripley Ballou in reviewing the entire manuscript and Box 1, respectively. The assistance from these individuals should not be construed as an endorsement of the views expressed in this article. The views expressed are those of the authors and do not necessarily reflect the official policy or position of the Department of the Navy, Department of Defense, nor the US Government. The study protocols for the clinical trials discussed in this manuscript that were performed by the US Navy or US Army were approved by the Naval Medical Research Center or Walter Reed Army Institute of Research Institutional Review Boards, respectively, in compliance with all applicable Federal regulations governing the protection of human subjects. Likewise, the animal experiments reported herein that were conducted by the US Navy or US Army were conducted in compliance with the Animal Welfare Act and in accordance with the principles set forth in the "Guide for the Care and Use of Laboratory Animals", Institute of Laboratory Animals Resources, National Research Council, National Academy Press, 1996. TLR is a military service member and SC and TDB are US Government employees. The work of SC, TDB and TLR was prepared as part of official government duties. Title 17 U.S.C. $§ 105$ provides that 'Copyright protection under this title is not available for any work of the United States Government'. Title 17 U.S.C. $§ 101$ defines a US Government work as a work prepared by a military service member or employee of the US Government as part of that person's official duties. The work was supported by work unit number 6000.RAD1.F

\section{References}

[1] Marsh K. Malaria disaster in Africa. Lancet 1998;352(9132).

[2] Nussenzweig RS, Vanderberg J, Most H, Orton C. Protective immunity produced by the injection of X-irradiated sporozoites of Plasmodium berghei. Nature 1967;216(5111):160-2.

[3] Dame JB, Williams JL, McCutchan TF, Weber JL, Wirtz RA, Hockmeyer WT, et al. Structure of the gene encoding the immunodominant surface antigen on the sporozoite of the human malaria parasite Plasmodium falciparum. Science 1984:225(4662):593-9.

[4] EneaV, Ellis J, Zavala F, Arnot DE, Asavanich A, Masuda A, et al. DNA cloning of Plasmodium falciparum circumsporozoite gene: amino acid sequence of repetitive epitope. Science 1984;225(4662):628-30.

[5] Zakeri S, Avazalipoor M, Mehrizi AA, Djadid ND, Snounou G. Restricted T-cell epitope diversity in the circumsporozoite protein from Plasmodium falciparum populations prevalent in Iran. Am J Trop Med Hyg 2007;76(6):104651.

[6] McCutchan TF, Kissinger JC, Touray MG, Rogers MJ, Li J, Sullivan M, et al. Comparison of circumsporozoite proteins from avian and mammalian malarias: biological and phylogenetic implications. Proc Natl Acad Sci U S A 1996;93:11889-94.

[7] Myung JM, Marshall P, Sinnis P. The Plasmodium circumsporozoite protein is involved in mosquito salivary gland invasion by sporozoites. Mol Biochem Parasitol 2004;133:53-9.

[8] Ying P, Shakibaei M, Patankar MS, Clavijo P, Beavis RC, Clark GF, et al. The malaria circumsporozoite protein: interaction of the conserved regions I and II-plus with heparin-like oligosaccharides in heparan sulfate. Exp Parasito 1997;85:168-82.

[9] Bermúdez A, Vanegas M, Patarroyo ME. Structural and immunological analysis of circumsporozoite protein peptides: a further step in the identification 
of potential components of a minimal subunit-based, chemically synthesised antimalarial vaccine. Vaccine 2008;26(52):6908-18.

[10] Good MF, Pombo DJ, Quakyi IA, Riley EM, Houghten RA, Menon A, et al. Human T-cell recognition of the circumsporozoite protein of Plasmodium falciparum: immunodominant T-cell domains map to the polymorphic regions of the molecule. Proc Natl Acad Sci U S A 1988;85(4):1199-203.

[11] Ballou WR, Hoffman SL, Sherwood JA, Hollingdale MR, Neva FA, Hockmeyer WT, et al. Safety and efficacy of a recombinant DNA Plasmodium falciparum sporozoite vaccine. Lancet 1987;1(8545):1277-81.

[12] Rickman LS, Gordon DM, Wistar R, Krzych U, Gross M, Hollingdale MR, et al. Use of adjuvant containing mycobacterial cell-wall skeleton, monophosphoryl lipid $\mathrm{A}$, and squalane in malaria circumsporozoite protein vaccine. Lancet 1991;337(8748):998-1001.

[13] Heppner DG, Gordon DM, Gross M, Wellde B, Leitner W, Krzych U, et al. Safety, immunogenicity, and efficacy of Plasmodium falciparum repeatless circumsporozoite protein vaccine encapsulated in liposomes. J Infect Dis 1996;174(2):361-6.

[14] Fries LF, Gordon DM, Schneider I, Beier JC, Long GW, Gross M, et al. Safety, immunogenicity, and efficacy of a Plasmodium falciparum vaccine comprising a circumsporozoite protein repeat region peptide conjugated to Pseudomonas aeruginosa toxin $\mathrm{A}$. Infect Immun 1992;60(5):1834-9.

[15] Herrington DA, Clyde DF, Losonsky G, Cortesia M, Murphy JR, Davis J, et al. Safety and immunogenicity in man of a synthetic peptide malaria vaccine against Plasmodium falciparum sporozoites. Nature 1987;328(6127):257-9.

[16] Noland GS, Hendel-Paterson B, Min XM, Moormann AM, Vulule JM, Narum $\mathrm{DL}$, et al. Low prevalence of antibodies to preerythrocytic but not blood-stage Plasmodium falciparum antigens in an area of unstable malaria transmission compared to prevalence in an area of stable malaria transmission. Infect Immun 2008;76(12):5721-8.

[17] Valenzuela P, Medina A, Rutter WJ, Ammerer G, Hall BD. Synthesis and assembly of hepatitis B virus surface antigen particles in yeast. Nature 1982;298(5872):347-50.

[18] Rutgers T, Gordon D, Gathoye AM, Hollingdale M, Hockmeyer W, Rosenberg $M$, et al. Hepatitis B surface antigen as carrier matrix for the repetitive epitope of the circumsporozoite protein of Plasmodium falciparum. Biotechnology 1988;6:1065-70.

[19] Gordon DM, McGovern TW, Krzych U, Cohen JC, Schneider I, LaChance R, et al. Safety, immunogenicity, and efficacy of a recombinantly produced Plasmodium falciparum circumsporozoite protein-hepatitis B surface antigen subunit vaccine. J Infect Dis 1995;171(6):1576-85.

[20] Coler RN, Carter D, Friede M, Reed SG. Adjuvants for malaria vaccines. Parasite Immunol 2009;31(9):520-8.

[21] Yang YW, Wei AC, Shen SS. The immunogenicity-enhancing effect of emulsion vaccine adjuvants is independent of the dispersion type and antigen release rate-a revisit of the role of the hydrophile-lipophile balance (HLB) value. Vaccine 2005;23:2665-75.

[22] Podda A, Del Giudice G. MF59-adjuvanted vaccines:increased immunogenicity with an optimal safety profile. Expert Rev Vaccines 2003;2:197-203.

[23] Persing DH, Coler RN, Lacy MJ, Johnson DA, Baldridge JR, Hershberg RM, et al. Taking toll: lipid A mimetics as adjuvants and immunomodulators. Trends Microbiol 2002;10(Suppl. 10):S32-7.

[24] Garcon N, Chomez P, van Mechelen M. GlaxoSmithKline adjuvant systems in vaccines: concepts, achievements and perspectives. Expert Rev Vaccines 2007;6:723-39.

[25] Richards RL, Rao M, Wassef NM, Glenn GM, Rothwell SW, Alving CR. Liposomes containing lipid A serve as an adjuvant for induction of antibody and cytotoxic T-cell responses against RTS,S malaria antigen. Infect Immun 1998;66(6):2859-65.

[26] Mettens P, Dubois PM, Demoitié MA, Bayat B, Donner MN, Bourguignon P, et al. Improved $T$ cell responses to Plasmodium falciparum circumsporozoite protein in mice and monkeys induced by a novel formulation of RTS,S vaccine antigen. Vaccine 2008;26(8):1072-82.

[27] Shott JP, McGrath SM, Pau MG, Custers JH, Ophorst O, Demoitie MA, et al. Adenovirus 5 and 35 vectors expressing Plasmodium falciparum circumsporozoite surface protein elicit potent antigen-specific cellular IFN-gamma and antibody responses in mice. Vaccine 2008;26(23):2818-23.

[28] Epstein JE, Rao S, Williams F, Freilich D, Luke T, Sedegah M, et al. Safety and clinical outcome of experimental challenge of human volunteers with Plasmodium falciparum-infected mosquitoes: an update. J Infect Dis 2007;196(1):145-54.

[29] Stoute JA, Slaoui M, Heppner DG, Momin P, Kester KE, Desmons P, et al. A preliminary evaluation of a recombinant circumsporozoite protein vaccine against Plasmodium falciparum malaria. RTS,S malaria vaccine evaluation group. $\mathrm{N}$ Engl J Med 1997;336(2):86-91.

[30] Kester KE, McKinney DA, Tornieporth N, Ockenhouse CF, Heppner DG, Hall $\mathrm{T}$, et al. Efficacy of recombinant circumsporozoite protein vaccine regimens against experimental Plasmodium falciparum malaria.J Infect Dis 2001;183(4): 640-7.

[31] Kester KE, McKinney D, Tornieporth N, Ockenhouse CF, Heppner DG, Hall T, et al. A phase I/Ila safety, immunogenicity, and efficacy bridging randomized study of a two-dose regimen of liquid and lyophilized formulations of the candidate malaria vaccine RTS,S/ASO2A in malaria-naïve adults. Vaccine 2007;25(29):5359-66

[32] Kester KE, Cummings JF, Ockenhouse CF, Nielsen R, Hall BT, Gordon DM, et al. Phase 2 a trial of 0,1 , and 3 month and 0,7 , and 28 day immunization schedules of malaria vaccine RTS,S/AS02 in malaria-naïve adults at the Walter Reed Army Institute of Research. Vaccine 2008;26(18):2191-202.
[33] Kester KE, Cummings JF, Ofori-Anyinam O, Ockenhouse CF, Krzych U, Moris $\mathrm{P}$, et al. Randomized, double-blind, phase $2 \mathrm{a}$ trial of falciparum malaria vaccines RTS,S/AS01B and RTS,S/AS02A in malaria-naive adults: safety, efficacy, and immunologic associates of protection. J Infect Dis 2009;200(3):337-46.

[34] Stoute JA, Kester KE, Krzych U, Wellde BT, Hall T, White K, et al. Long-term efficacy and immune responses following immunization with the RTS,S malaria vaccine. J Infect Dis 1998;178(4):1139-44.

[35] Jiang G, Shi M, Conteh S, Richie N, Banania G, Geneshan H, et al. Sterile protection against Plasmodium knowlesi in rhesus monkeys from a malaria vaccine: comparison of heterologous prime boost strategies. PLoS One 2009;4(8):e6559.

[36] Stewart VA, McGrath SM, Dubois PM, Pau MG, Mettens P, Shott J, et al. Priming with an adenovirus 35-circumsporozoite protein (CS) vaccine followed by RTS,S/AS01B boosting significantly improves immunogenicity to Plasmodium falciparum CS compared to that with either malaria vaccine alone. Infect Immun 2007;75(5):2283-90.

[37] Walsh DS, Gettayacamin M, Leitner WW, Lyon JA, Stewart VA, Marit G, et al. Heterologous prime-boost immunization in rhesus macaques by two, optimally spaced particle-mediated epidermal deliveries of Plasmodium falciparum circumsporozoite protein-encoding DNA, followed by intramuscular RTS,S/AS02A. Vaccine 2006;24(19):4167-78.

[38] Wang R, Epstein J, Charoenvit Y, Baraceros FM, Rahardjo N, Gay T, et al. Induction in humans of CD8+ and CD4+ T cell and antibody responses by sequential immunization with malaria DNA and recombinant protein. J Immunol 2004;172(9):5561-9.

[39] Dunachie SJ, Walther M, Vuola JM, Webster DP, Keating SM, Berthoud T, et al. A clinical trial of prime-boost immunisation with the candidate malaria vaccines RTS,S/AS02A and MVA-CS. Vaccine 2006;24(15):2850-9.

[40] Dunachie SJ, Walther M, Epstein JE, Keating S, Berthoud T, Andrews L, et al. A DNA prime-modified vaccinia virus ankara boost vaccine encoding thrombospondin-related adhesion protein but not circumsporozoite protein partially protects healthy malaria-naive adults against Plasmodium falciparum sporozoite challenge. Infect Immun 2006;74(10):5933-42.

[41] Walther M, Thompson FM, Dunachie S, Keating S, Todryk S, Berthoud T, et al. Safety, immunogenicity, and efficacy of prime-boost immunization with recombinant poxvirus FP9 and modified vaccinia virus Ankara encoding the full-length Plasmodium falciparum circumsporozoite protein. Infect Immun 2006;74(5):2706-16.

[42] Bejon P, Andrews L, Andersen RF, Dunachie S, Webster D, Walther M, et al. Calculation of liver-to-blood inocula, parasite growth rates, and preerythrocytic vaccine efficacy, from serial quantitative polymerase chain reaction studies of volunteers challenged with malaria sporozoites. J Infect Dis 2005;191(4):619-26.

[43] Doolan DL, Dobaño C, Baird JK. Acquired immunity to malaria. Clin Microbiol Rev 2009;22(1):13-36.

[44] Guinovart C, Aponte JJ, Sacarlal J, Aide P, Leach A, Bassat Q et al. Insights into long-lasting protection induced by RTS,S/AS02A malaria vaccine: further results from a phase IIb trial in Mozambican children. PLoS One 2009;4(4):e5165

[45] Bojang KA, Milligan PJ, Pinder M, Vigneron L, Alloueche A, Ballou WR, et al. Efficacy of RTS,S/ASO2 malaria vaccine against Plasmodium falciparum infection in semi-immune adult men in The Gambia: a randomised trial. Lancet 2001;358(9297):1927-34.

[46] Polhemus ME, Remich SA, Ogutu BR, Waitumbi JN, Otieno L, Apollo S, et al. Evaluation of RTS,S/AS02A and RTS,S/AS01B in adults in a high malaria transmission area. PLoS One 2009;4(7):e6465.

[47] Alonso PL, Sacarlal J, Aponte JJ, Leach A, Macete E, Milman J, et al. Efficacy of the RTS,S/AS02A vaccine against Plasmodium falciparum infection and disease in young African children: randomised controlled trial. Lancet 2004;364(9443):1411-20.

[48] Alonso PL, Sacarlal J, Aponte JJ, Leach A, Macete E, Aide P, et al. Duration of protection with RTS,S/AS02A malaria vaccine in prevention of Plasmodium falciparum disease in Mozambican children: single-blind extended follow-up of a randomised controlled trial. Lancet 2005;366(9502): 2012-8.

[49] Sacarlal J, Aide P, Aponte JJ, Renom M, Leach A, Mandomando I, et al. Long-term safety and efficacy of the RTS,S/AS02A malaria vaccine in Mozambican children. J Infect Dis 2009;200(3):329-36.

[50] Aponte JJ, Aide P, Renom M, Mandomando I, Bassat Q, Sacarlal J, et al. Safety of the RTS,S/ASO2D candidate malaria vaccine in infants living in a highly endemic area of Mozambique: a double blind randomised controlled phase I/IIb trial. Lancet 2007;370(9598):1543-51.

[51] Abdulla S, Oberholzer R, Juma O, Kubhoja S, Machera F, Membi C, et al. Safety and immunogenicity of RTS,S/ASO2D malaria vaccine in infants. N Engl J Med 2008;359(24):2533-44.

[52] Bejon P, Lusingu J, Olotu A, Leach A, Lievens M, Vekemans J, et al. Efficacy of RTS,S/AS01E vaccine against malaria in children 5 to 17 months of age. $\mathrm{N} \mathrm{Engl}$ J Med 2008;359(24):2521-32.

[53] Macete EV, Sacarlal J, Aponte JJ, Leach A, Navia MM, Milman J, et al. Evaluation of two formulations of adjuvanted RTS,S malaria vaccine in children aged 3 to 5 living in a malaria-endemic region of Mozambique: a Phase I/IIb randomized double-blind bridging trial. Trails 2007;8:11.

[54] Greenwood B, Targett G. Do we still need a malaria vaccine? Parasite Immunol 2009;31(9):582-6.

[55] Alloueche A, Milligan P, Conway DJ, Pinder M, Bojang K, Doherty T, et al. Protective efficacy of the RTS,S/AS02 Plasmodium falciparum malaria vaccine is not strain specific. Am J Trop Med Hyg 2003;68(1):97-101. 
[56] Enosse S, Dobano C, Quelhas D, Aponte JJ, Lievens M, Leach A, et al. RTS,S/AS02A malaria vaccine does not induce parasite CSP T cell epitope selection and reduces multiplicity of infection. PLoS Clin Trials 2006;1(1):e5.

[57] Overstreet MG, Cockburn IA, Chen YC, Zavala F. Protective CD8 T cells against Plasmodium liver stages: immunobiology of an 'unnatural' immune response. Immunol Rev 2008;225:272-83.

[58] Grüner AC, Mauduit M, Tewari R, Romero JF, Depinay N. Sterile protection against malaria is independent of immune responses to the circumsporozoite protein. PLoS One 2007;2(12):e1371.

[59] Lalvani A, Moris P, Voss G, Pathan AA, Kester KE, Lee E, et al. Potent induction of focused Th1-type cellular and humoral responses by RTS,S/SBAS2, a recombinant Plasmodium falciparum malaria vaccine. J Infect Dis 1999;180(5):1656-64.

[60] Stoute JA, Heppner DG, Mason CJ, Siangla J, Opollo MO, Kester KE, et al. Phase safety and immunogenicity trial of malaria vaccine RTS,S/AS02A in adults in a hyperendemic region of estern Kenya. Am J Trop Med Hyg 2006;75(1):166-70.

[61] Doherty JF, Pinder M, Tornieporth N, Carton C, Vigneron L, Milligan P, et al. A phase I safety and immunogenicity trial with the candidate malaria vaccine RTS,S/SBAS2 in semi-immune adults in The Gambia. Am J Trop Med Hyg 1999;61(6):865-8.

[62] Macete E, Aponte JJ, Guinovart C, Sacarlal J, Ofori-Anyinam O, Mandomando I, et al. Safety and immunogenicity of the RTS,S/AS02A candidate malaria vaccine in children aged 1-4 in Mozambique. Trop Med Int Health 2007;12(1):37-46.

[63] Bojang KA, Olodude F, Pinder M, Ofori-Anyinam O, Vigneron L, Fitzpatrick S et al. Safety and immunogenicity of RTS,S/AS02A candidate malaria vaccine in Gambian children. Vaccine 2005;23(32):4148-57.

[64] Owusu-Agyei S, Ansong D, Asante K, Kwarteng Owusu SK, Owusu R, Wireko Brobby NA, et al. Randomized controlled trial of RTS,S/AS02D and RTS,S/AS01E malaria candidate vaccines given According to Different Schedules in Ghanaian Children according to different schedules in Ghanaian children. PLOS One 2009;4(10):e7302.

[65] Lell B, Agnandji S, von Glasenapp I, Haertle S, Oyakhiromen S, Issifou S, et al. A randomized trial assessing the safety and immunogenicity of AS01 and AS02 adjuvanted RTS,S malaria vaccine candidates in children in Gabon. PLoS One 2009;4(10):e7611.

[66] Schwenk R, Asher LV, Chalom I, Lanar D, Sun P, White K, et al. Opsonization by antigen-specific antibodies as a mechanism of protective immunity induced by lpasmodium falciparum circumsporozoite protein-based vaccine. Parasite Immunol 2003;25(1):17-25.

[67] Sun P, Schwenk R, White K, Stoute JA, Cohen J, Ballou WR, et al. Protective immunity induced with malaria vaccine, RTS,S, is linked to Plasmodium falciparum circumsporozoite protein-specific CD4 and CD8 T Cells producing IFN $\gamma$. J Immunol 2003;171(12):6961-7.
[68] Barbosa A, Naniche D, Aponte JJ, Manaca MN, Mandomando I, Aide P, et al. Plasmodium falciparum-specific cellular immune responses after immunization with the RTS,S/AS02D candidate malaria vaccine in infants living in an area of high endemicity in Mozambique. Infect Immun 2009;77(10): 4502-9.

[69] Casares S, Brumeanu TD. Insights into the pathogenesis of type 1 diabetes: a hint for novel immunospecific therapies. Curr Mol Med 2001;1(3):357-8.

[70] Casares S, Richie TL. Immune evasion by malaria parasites: a challenge for vaccine development. Curr Opin Immunol 2009;21(3):321-30.

[71] Apostolou I, Verginis P, Kretschmer K, Polansky J, Hühn J, von Boehmer H. Peripherally induced Treg: mode, stability, and role in specific tolerance. J Clin Immunol 2008;28(6):619-24.

[72] Fletcher HA, Pathan AA, Berthoud TK, Dunachie SJ, Whelan KT, Alder NC, et al. Boosting BCG vaccination with MVA85A down-regulates the immunoregulatory cytokine TGF-beta1. Vaccine 2008;26(41):5269-75.

[73] Vahey M, Wang Z, Kester KE, Cummings J, Heppner DG, Nau ME, et al. Expression of genes associated with immunoproteosome processing of major histocompatibility complex peptides is indicative of protection with adjuvanted RTS,S malaria vaccine. J Infect Dis 2010;201(4):580-9.

[74] Rechsteiner M, Hill CP. Mobilizing the proteolytic machine: cell biological roles of proteasome activators and inhibitors. Trends Cell Biol 2005;15(1):2733.

[75] Weiss WR, Kumar A, Jiang G, Williams J, Bostick A, Conteh S, et al. Protection of rhesus monkeys by a DNA prime/poxvirus boost malaria vaccine depends on optimal DNA priming and inclusion of blood stage antigens. PLoS One 2007;2(10):e1063.

[76] Jiang G, Charoenvit Y, Moreno A, Baraceros MF, Banania G, Richie N, et al. Induction of multi-antigen multi-stage immune responses against Plasmodium falciparum in rhesus monkeys, in the absence of antigen interference, with heterologous DNA prime/poxvirus boost immunization. Malar J 2007;6:135

[77] Vaughan AM, Wang R, Kappe SH. Genetically engineered, attenuated wholecell vaccine approaches for malaria. Hum Vaccin 2010; 6(1) [Epub ahead of print]

[78] van Dijk MR, Douradinha B, Franke-Fayard B, Heussler V, van Dooren MW van Schaijk B et al. Genetically attenuated, P36p-deficient malarial sporozoites induce protective immunity and apoptosis of infected liver cells. Proc Natl Acad Sci U S A 2005;102(34):12194-9.

[79] Moorthy V, Reed Z, Smith PG. MALVAC 2008: measures of efficacy of malaria vaccines in phase $2 \mathrm{~b}$ and phase 3 trials-scientific, regulatory and public health perspectives. Vaccine 2009;27(5):624-8

[80] Smith PG, Rodrigues LC, Fine PE. Assesment of the protective efficacy of vaccines against common diseases using case-control and cohort studies. Int J Epidemiol 1984;13(1):87-93. 